\title{
Environmental factors influencing benthic communities in the oxygen minimum zones on the Angolan and Namibian margins
}

\author{
Ulrike Hanz $^{1}$, Claudia Wienberg ${ }^{2}$, Dierk Hebbeln ${ }^{2}$, Gerard Duineveld $^{1}$, Marc Lavaleye ${ }^{1}$, Katriina Juva ${ }^{3}$, \\ Wolf-Christian Dullo $^{3}$, André Freiwald ${ }^{4}$, Leonardo Tamborrino ${ }^{2}$, Gert-Jan Reichart ${ }^{1,5}$, Sascha Flögel ${ }^{3}$, and \\ Furu Mienis ${ }^{1}$ \\ ${ }^{1}$ Department of Ocean Systems, NIOZ Royal Netherlands Institute for Sea Research and Utrecht University, \\ Texel, 1797SH, the Netherlands \\ ${ }^{2}$ MARUM-Center for Marine Environmental Sciences, University of Bremen, 28359 Bremen, Germany \\ ${ }^{3}$ GEOMAR Helmholtz Centre for Ocean Research, 24148 Kiel, Germany \\ ${ }^{4}$ Department for Marine Research, Senckenberg Institute, 26382 Wilhelmshaven, Germany \\ ${ }^{5}$ Faculty of Geosciences, Earth Sciences Department, Utrecht University, Utrecht, 3512JE, the Netherlands
}

Correspondence: Ulrike Hanz (ulrike.hanz@nioz.nl)

Received: 7 February 2019 - Discussion started: 25 February 2019

Revised: 3 October 2019 - Accepted: 10 October 2019 - Published: 15 November 2019

\begin{abstract}
Thriving benthic communities were observed in the oxygen minimum zones along the southwestern African margin. On the Namibian margin, fossil cold-water coral mounds were overgrown by sponges and bryozoans, while the Angolan margin was characterized by cold-water coral mounds covered by a living coral reef. To explore why benthic communities differ in both areas, present-day environmental conditions were assessed, using conductivitytemperature-depth (CTD) transects and bottom landers to investigate spatial and temporal variations of environmental properties. Near-bottom measurements recorded low dissolved oxygen concentrations on the Namibian margin of $0-0.15 \mathrm{~mL} \mathrm{~L}^{-1}(\triangleq 0 \%-9 \%$ saturation) and on the Angolan margin of $0.5-1.5 \mathrm{~mL} \mathrm{~L}^{-1}(\triangleq 7 \%-18 \%$ saturation), which were associated with relatively high temperatures (11.8-13.2 ${ }^{\circ} \mathrm{C}$ and $6.4-12.6^{\circ} \mathrm{C}$, respectively). Semidiurnal barotropic tides were found to interact with the margin topography producing internal waves. These tidal movements deliver water with more suitable characteristics to the benthic communities from below and above the zone of low oxygen. Concurrently, the delivery of a high quantity and quality of organic matter was observed, being an important food source for the benthic fauna. On the Namibian margin, organic matter originated directly from the surface productive zone, whereas on the Angolan margin the geochemical signature of organic matter suggested an additional mechanism
\end{abstract}

of food supply. A nepheloid layer observed above the coldwater corals may constitute a reservoir of organic matter, facilitating a constant supply of food particles by tidal mixing. Our data suggest that the benthic fauna on the Namibian margin, as well as the cold-water coral communities on the Angolan margin, may compensate for unfavorable conditions of low oxygen levels and high temperatures with enhanced availability of food, while anoxic conditions on the Namibian margin are at present a limiting factor for coldwater coral growth. This study provides an example of how benthic ecosystems cope with such extreme environmental conditions since it is expected that oxygen minimum zones will expand in the future due to anthropogenic activities.

\section{Introduction}

Cold-water corals (CWCs) form 3-D structures in the deep sea, providing important habitats for dense aggregations of sessile and mobile organisms ranging from mega- to macrofauna (Henry and Roberts, 2007; van Soest et al., 2007) and fish (Costello et al., 2005). Consequently, CWC areas are considered as deep-sea hotspots of biomass and biodiversity (Buhl-Mortensen et al., 2010; Henry and Roberts, 2017). Moreover, they form hotspots for carbon cycling by transferring carbon from the water column towards associated ben- 
thic organisms (Oevelen et al., 2009; White et al., 2012). Some framework-forming scleractinian species, with Lophelia pertusa and Madrepora oculata being the most common species in the Atlantic Ocean (Freiwald et al., 2004; White et al., 2005; Roberts et al., 2006; Cairns, 2007), are capable of forming large elevated seabed structures, so-called coral mounds (Wilson, 1979; Wienberg and Titschack, 2017; Titschack et al., 2015; De Haas et al., 2009). These coral mounds, consisting of coral debris and hemipelagic sediments, commonly reach heights between 20 and $100 \mathrm{~m}$ and can be several kilometers in diameter. They are widely distributed along the North Atlantic margins, being mainly restricted to water depths between 200 and $1000 \mathrm{~m}$, while records of single colonies of $L$. pertusa are reported from a broader depth range of 50-4000 $\mathrm{m}$ depth (Roberts et al., 2006; Hebbeln et al., 2014; Davies et al., 2008; Mortensen et al., 2001; Freiwald et al., 2004; Freiwald, 2002; Grasmueck et al., 2006; Wheeler et al., 2007).

A global ecological-niche factor analysis by Davies et al. (2008) and Davies and Guinotte (2011), predicting suitable habitats for $L$. pertusa, showed that this species generally thrives in areas which are nutrient rich, well oxygenated and affected by relatively strong bottom water currents. Other factors potentially important for proliferation of $L$. pertusa include chemical and physical properties of the ambient water masses, for example aragonite saturation state, salinity and temperature (Davies et al., 2008; Dullo et al., 2008; Flögel et al., 2014; Davies and Guinotte, 2011). L. pertusa is most commonly found at temperatures between 4 and $12{ }^{\circ} \mathrm{C}$ and a very wide salinity range between 32 and 38.8 (Freiwald et al., 2004). The link of L. pertusa to particular salinity and temperature within the NE Atlantic led Dullo et al. (2008) to suggest that they are restricted to a specific density envelope of sigma-theta $(\sigma \Theta)=27.35$ $27.65 \mathrm{~kg} \mathrm{~m}^{-3}$. In addition, the majority of occurrences of live L. pertusa comes from sites with dissolved oxygen (DO) concentrations between 6 and $6.5 \mathrm{mLL}^{-1}$ (Davies et al., 2008), with lowest recorded oxygen values being $2.1-3.2 \mathrm{mLL}^{-1}$ at CWC sites in the Gulf of Mexico (Davies et al., 2010; Schroeder, 2002; Brooke and Ross, 2014) or even as low as $1-1.5 \mathrm{~mL} \mathrm{~L}^{-1}$ off Mauritania, where CWC mounds are in a dormant stage presently showing only scarce living coral occurrences (Wienberg et al., 2018; Ramos et al., 2017). Dissolved oxygen levels hence seem to affect the formation of CWC structures as was also shown by Holocene records obtained from the Mediterranean Sea, which revealed periods of reef demise and growth in conjunction with hypoxia (with $2 \mathrm{~mL} \mathrm{~L}^{-1}$ seemingly forming a threshold value for active coral growth; Fink et al., 2012).

Another essential constraint for CWC growth and therefore mound development in the deep sea is food supply. $L$. pertusa is an opportunistic feeder, exploiting a wide variety of different food sources, including phytodetritus, phytoplankton, mesozooplankton, bacteria and dissolved organic matter (Kiriakoulakis et al., 2005; Dodds et al., 2009; Gori et al., 2014; Mueller et al., 2014; Duineveld et al., 2007). Not only quantity but also quality of food particles are of crucial importance for the uptake efficiency as well as ecosystem functioning of CWCs (Ruhl, 2008; Mueller et al., 2014). Transport of surface organic matter towards CWC sites at intermediate water depths has been found to involve either active swimming (zooplankton), passive sinking, advection, local downwelling, and internal waves and associated mixing processes resulting from interactions with topography (Davies et al., 2009; van Haren et al., 2014; Thiem et al., 2006; White et al., 2005; Mienis et al., 2009; Frederiksen et al., 1992). With worldwide efforts to map CWC communities, $L$. pertusa was also found under conditions which are environmentally stressful or extreme in the sense of the global limits defined by Davies et al. (2008) and by Davies and Guinotte (2011). Examples are the warm and salty waters of the Mediterranean and the high bottom water temperatures along the US coast (Cape Lookout; Freiwald et al., 2009; Mienis et al., 2014; Taviani et al., 2005). Environmental stress generally increases energy needs for organisms to recover and maintain optimal functioning, which accordingly increases their food demand (Sokolova et al., 2012).

For the SW African margin one of the few records of living CWC comes from the Angolan margin (at $7^{\circ} \mathrm{S}$; Le Guilloux et al., 2009), which raises the questions whether environmental factors limit CWC growth due to the presence of an oxygen minimum zone (OMZ; see Karstensen et al. 2008), or whether this is related to a lack of data. Hydroacoustic campaigns revealed extended areas off Angola and Namibia with structures that morphologically resemble coral mound structures known from the NE Atlantic (M76-3, MSM20-1; Geissler et al., 2013; Zabel et al., 2012). Therefore two of such mound areas on the margins off Namibia and Angola were visited during the RV Meteor cruise M122 "ANNA" (ANgola and NAmibia) in January 2016 (Hebbeln et al., 2017). During this cruise, fossil CWC mound structures were found near Namibia, while flourishing CWC reef-covered mound structures were observed on the Angolan margin. The aim of the present study was to assess present-day environmental conditions at the southwestern African margin to explore why CWCs thrive on the Angolan margin and are absent on the Namibian margin. Key parameters influencing CWCs, hydrographic parameters as well as chemical properties of the water column were measured to characterize the difference in environmental conditions and food supply. These data are used to improve understanding of the potential fate of CWC mounds in a changing ocean. 


\section{Material and methods}

\subsection{Setting}

\subsubsection{Oceanographic setting}

The SW African margin is one of the four major eastern boundary regions in the world and is characterized by upwelling of nutrient-rich cold waters (Shannon and Nelson, 1996). The availability of nutrients triggers a high primary production, making it one of the most productive marine areas worldwide with an estimated production of $0.37 \mathrm{Gt} \mathrm{C} \mathrm{yr}^{-1}$ (Carr and Kearns, 2003). Remineralization of high fluxes of organic particles settling through the water column results in severe mid-depth oxygen depletion and an intense OMZ over large areas along the SW African margin (Chapman and Shannon, 1985). The extension of the OMZ is highly dynamic, being controlled by upwelling intensity, which depends on the prevailing winds and two current systems along the SW African margin, i.e., the Benguela and the Angola currents (Kostianoy and Lutjeharms, 1999; Chapman and Shannon, 1987; Fig. 1). The Benguela Current originates from the South Atlantic Current, which mixes with water from the Indian Ocean at the southern tip of Africa (Poole and Tomczak, 1999; Mohrholz et al., 2008; Rae, 2005) and introduces relatively cold and oxygen-rich Eastern South Atlantic Central Water (ESACW; Poole and Tomczak, 1999) to the SW African margin (Mohrholz et al., 2014). The Angola Current originates from the South Equatorial Counter Current and introduces warmer, nutrient-poor and less oxygenated South Atlantic Central Water (SACW; Poole and Tomczak, 1999) to the continental margin (Fig. 1a). SACW is defined by a linear relationship between temperature and salinity in a $T-S$ plot (Shannon et al., 1987). While the SACW flows along the continental margin the oxygen concentration is decreasing continuously due to remineralization processes of organic matter on the SW African shelf (Mohrholz et al., 2008). Both currents converge at around $14-16^{\circ} \mathrm{S}$, resulting in the Angola-Benguela front (Lutjeharms and Stockton, 1987). In austral summer, the AngolaBenguela front can move southward to $23^{\circ} \mathrm{S}$ (Shannon et al., 1986), thus increasing the influence of the SACW along the Namibian coast (Junker et al., 2017; Chapman and Shannon, 1987), contributing to the pronounced OMZ due to its low initial oxygen concentration (Poole and Tomczak, 1999). ESACW is the dominant water mass at the Namibian margin during the main upwelling season in austral winter, expanding from the oceanic zone about $350 \mathrm{~km}$ towards the coast (Mohrholz et al., 2014). The surface water mass at the Namibian margin is a mixture of sun-warmed upwelled water and water of the Agulhas Current, which mixes in complex eddies and filaments and is called South Atlantic Subtropical Surface Water (SASSW) (Hutchings et al., 2009). At the Angolan margin the surface water is additionally influenced by water from the Cuanza and Congo rivers (Kopte et al., 2017,
Fig. 1). Antarctic Intermediate Water (AAIW) is situated in deeper areas at the African continental margin and can be identified as the freshest water mass around 700-800 $\mathrm{m}$ depth (Shannon and Nelson, 1996).

\subsubsection{Coral mounds along the Angolan and Namibian margins}

During RV Meteor cruise M122 in 2016, over 2000 coral mounds were observed between 160 and $260 \mathrm{~m}$ water depth on the Namibian shelf (Hebbeln et al., 2017). All mounds were densely covered with coral rubble and dead coral framework, while no living corals were observed in the study area (Hebbeln et al., 2017; Fig. 2a, b). Few species were locally very abundant, viz. a yellow cheilostome bryozoan which was the most common species, and five sponge species. The bryozoans were encrusting the coral rubble, whereas some sponge species reached heights of up to $30 \mathrm{~cm}$ (Fig. 2a, b). The remaining community consisted of an impoverished fauna overgrowing $L$. pertusa debris. Commonly found sessile organism were actiniarians, zoanthids, hydroids, some thin encrusting sponges, serpulids and sabellid polychaetes. The mobile fauna comprised asteroids, ophiuroids, two shrimp species, amphipods, cumaceans and holothurians. Locally high abundances of Suffogobius bibarbatus, a fish that is known to be adapted to hypoxic conditions, were observed in cavities in the coral framework (Hebbeln, 2017). Dead corals collected from the surface of various Namibian mounds date back to about $5 \mathrm{ka}$ pointing to a simultaneous demise of these mounds during the mid-Holocene (Tamborrino et al., 2019).

On the Angolan margin CWC structures varied from individual mounds to long ridges. Some mounds reached heights of more than $100 \mathrm{~m}$ above the seafloor. At shallow depths $(\sim 250 \mathrm{~m})$ some isolated smaller mounds were also present (Hebbeln et al. 2017). All mounds showed a thriving CWC cover, which was dominated by L. pertusa (estimated $99 \%$ relative abundance), along with some $M$. oculata and solitary corals. Mounds with a flourishing coral cover were mainly situated at water depths between 330 and $470 \mathrm{~m}$, whereas single colonies were found over a broader depth range between 250 and $500 \mathrm{~m}$ (Fig. 2c, d; Hebbeln et al., 2017). Additionally, large aggregations of hexactinellid sponges (Aphrocallistes, Sympagella) were observed. First estimates for coral ages obtained from a gravity core collected at one of the Angolan coral mounds revealed continuous coral mound formation during the last $34 \mathrm{kyr}$ until today (Wefing et al., 2017).

\subsection{Methodology}

During RV Meteor expedition M122 in January 2016, two conductivity-temperature-depth (CTD) transects and three short-term bottom lander deployments (Table 1, Fig. 1) were carried out to measure environmental conditions influencing benthic habitats. In addition, weather data were continuously 
(a)

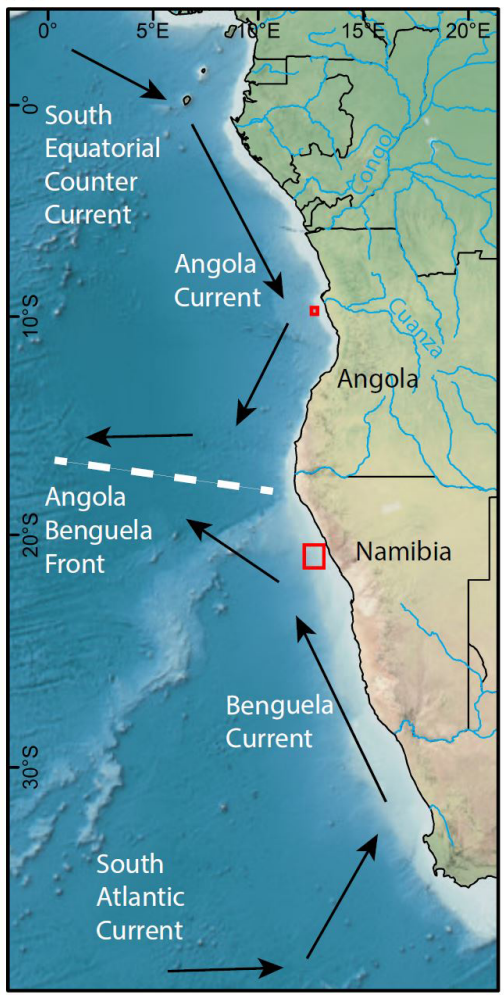

(b)
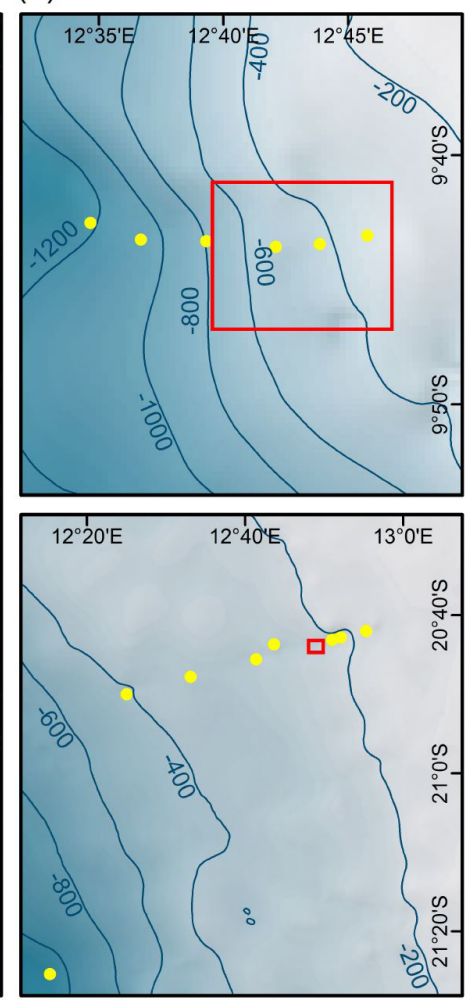

(c)
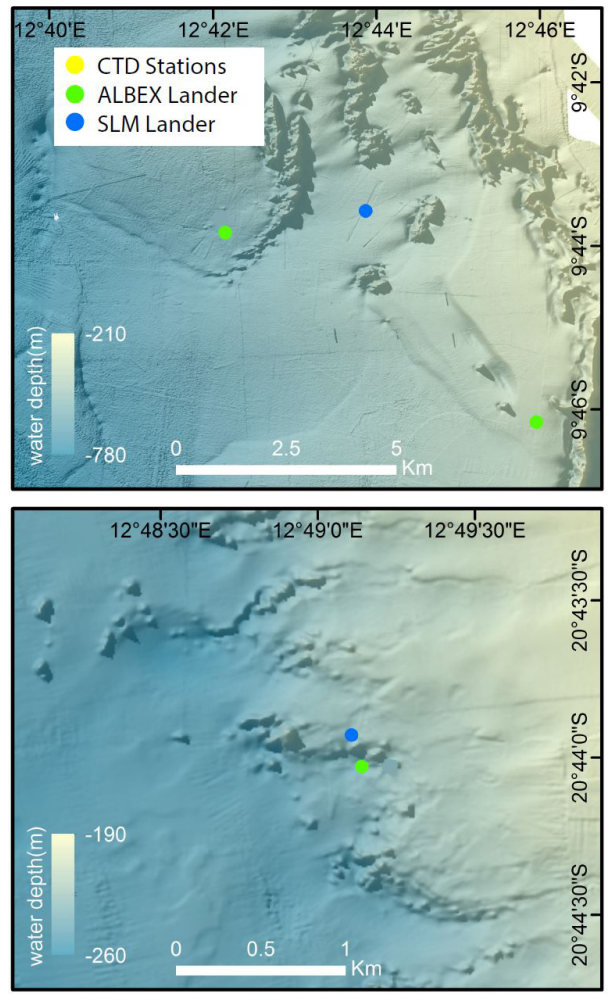

Figure 1. (a) Overview map showing the research areas off Angola and Namibia (red squares) and main features of the surface water circulation (arrows) and frontal zone (dashed line) as well as the two main rivers discharging at the Angolan margin. Detailed bathymetry maps of the Angolan (upper maps) and Namibian margins (lower maps) showing the position of (b) CTD transects (note the deep CTD cast down to $1000 \mathrm{~m}$ water depth conducted off Namibia) and (c) bottom lander deployments (red squares shown in $\mathbf{b}$ indicate the cutouts displayed in $\mathbf{c}$ ).

recorded by the RV Meteor weather station, providing realtime information on local wind speed and wind direction.

\subsubsection{Lander deployments}

Sites for deployment of the NIOZ-designed lander (ALBEX) were selected based on multibeam bathymetric data. On the Namibian margin the bottom lander was deployed on top of a mound structure (water depth $220 \mathrm{~m}$ ). Off Angola the lander was deployed in the relatively shallow part of the mound zone at $340 \mathrm{~m}$ water depth and in the deeper part at $530 \mathrm{~m}$ (Fig. 1, Table 1). Additionally, a GEOMAR satellite lander module (SLM) was deployed off-mound at $230 \mathrm{~m}$ depth at the Namibian margin and at $430 \mathrm{~m}$ depth at the Angolan margin (Fig. 1, Table 1). The lander was equipped with an AROUSB oxygen sensor (JFE Advantech ${ }^{\mathrm{TM}}$ ), a combined OBSfluorometer (Wet Labs ${ }^{\mathrm{TM}}$ ) and an Aquadopp (Nortek ${ }^{\mathrm{TM}}$ ) profiling current meter. The lander was furthermore equipped with a Technicap PPS4/3 sediment trap with 12 bottles (allowing daily samples) and a McLane particle pump (24 filter units for each $7.5 \mathrm{~L}$ of seawater, $2 \mathrm{~h}$ interval) to sample partic- ulate organic matter in the near-bottom water $(40 \mathrm{~cm}$ above bottom).

The SLM was equipped with a $600 \mathrm{kHz}$ ADCP Workhorse Sentinel 600 from RDI, a CTD (SBE SBE16V2 ${ }^{\mathrm{TM}}$ ), a combined fluorescence and turbidity sensor (WET Labs ECO$\mathrm{AFL} / \mathrm{FL})$, a dissolved oxygen sensor $\left(\mathrm{SBE}^{\mathrm{TM}}\right)$ and a $\mathrm{pH}$ sensor $\left(\mathrm{SBE}^{\mathrm{TM}}\right)$ (Hebbeln et al., 2017). From the SLM only pH measurements are used here, complementing the data from the NIOZ lander.

\subsubsection{CTD transects}

Vertical profiles of hydrographic parameters in the water column, viz. temperature, conductivity, oxygen and turbidity, were obtained using a Sea-Bird CTD-Rosette system (SeaBird SBE 9 plus). The additional sensors on the CTD were a dissolved oxygen sensor (SBE 43 membrane-type DO Sensor) and a combined fluorescence and turbidity sensor (WET Labs ECO-AFL/FL). The CTD was combined with a rosette water sampler consisting of 24 Niskin ${ }^{\circledR}$ water sampling bottles $(10 \mathrm{~L})$. CTD casts were carried out along two downslope 

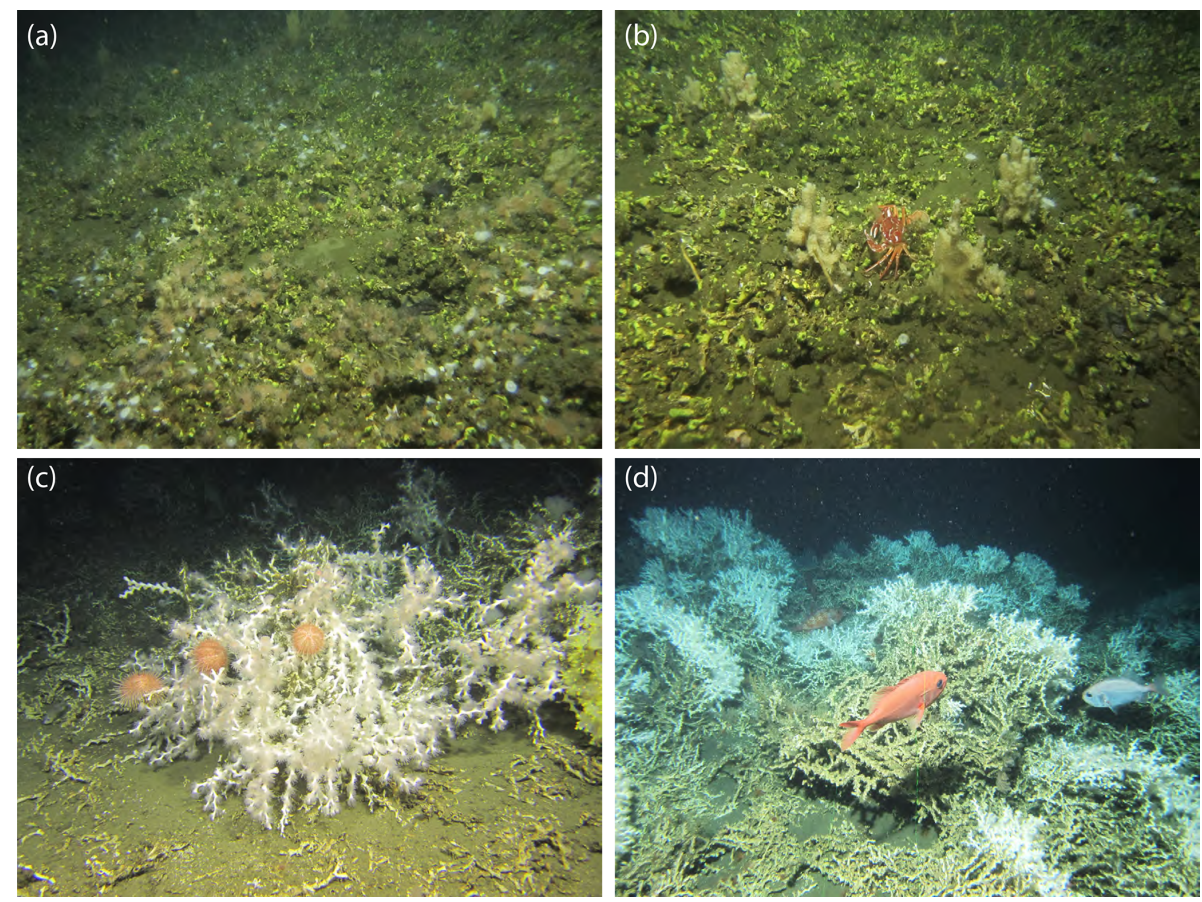

Figure 2. ROV images (copyright MARUM ROV SQUID, Bremen, Germany) showing the surface coverage of cold-water coral mounds discovered off Namibia (a, b) and Angola (c, d). Images were recorded and briefly described for their faunal composition during RV Meteor cruise M122 "ANNA" (see Hebbeln et al., 2017). (a) Sylvester mound, $225 \mathrm{~m}$ water depth. Dead coral framework entirely consisting of L. pertusa. The framework is intensely colonized by the yellow bryozoan Metropriella sp., zoanthids, actiniarians and sponges. Vagile fauna consists of asteroids and gobiid fishes (Sufflogobius bibarbatus) that hide in hollows in the coral framework. (b) Sylvester mound, $238 \mathrm{~m}$ water depth. Dense coral rubble (L. pertusa) heavily overgrown by Metropriella sp. and sponges. Note the decapod crab Macropipus australis (center of the image). (c) Valentine mound, $238 \mathrm{~m}$ water depth. Live L. pertusa colony being grazed by echinoids. Note the sponge Aphrocallistes sp. with its actiniarian symbionts (right side of the image). (d) Buffalo mound, $345 \mathrm{~m}$ water depth. Living CWC reef observed on top of an Angolan coral mound. Many fishes are present around the reef (Helicolenus dactylopterus, Gephyroberyx darwinii).

Table 1. Metadata of lander deployments conducted during RV Meteor cruise M122 (ANNA) in January 2016. The deployment sites are shown in Fig. 1.

\begin{tabular}{|c|c|c|c|c|c|c|c|c|c|}
\hline & $\begin{array}{l}\text { Station no. } \\
\text { (GeoB ID) }\end{array}$ & Area & Lander & $\begin{array}{l}\text { Date } \\
\text { (dd.mm.yy) }\end{array}$ & $\begin{array}{l}\text { Latitude } \\
\text { (S) }\end{array}$ & $\begin{array}{l}\text { Longitude } \\
\text { (E) }\end{array}$ & $\begin{array}{r}\text { Depth } \\
(\mathrm{m})\end{array}$ & $\begin{array}{r}\text { Duration } \\
\text { (d) }\end{array}$ & Devices \\
\hline \multirow[t]{2}{*}{ Namibia } & $20507-1$ & on-mound & ALBEX & $01-09.01 .16$ & $20^{\circ} 44.03^{\prime}$ & $12^{\circ} 49.23^{\prime}$ & 210 & 7.8 & \multirow{2}{*}{$\begin{array}{l}+ \text { particle } \\
\text { pump }\end{array}$} \\
\hline & $20506-1$ & off-mound & SLM & $01-16.01 .16$ & $20^{\circ} 43.93^{\prime}$ & $12^{\circ} 49.11^{\prime}$ & 230 & 12.5 & \\
\hline \multirow[t]{3}{*}{ Angola } & 20921-1 & off-mound & ALBEX & $20-23.01 .16$ & $9^{\circ} 46.16^{\prime}$ & $12^{\circ} 45.96^{\prime}$ & 340 & 2.5 & $\begin{array}{l}+ \text { particle } \\
\text { pump }\end{array}$ \\
\hline & 20940-1 & off-mound & ALBEX & $23-26.01 .16$ & $9^{\circ} 43.84^{\prime}$ & $12^{\circ} 42.15^{\prime}$ & 530 & 2.6 & \multirow{2}{*}{$\begin{array}{l}+ \text { particle } \\
\text { pump }\end{array}$} \\
\hline & 20915-2 & off-mound & SLM & $19-26.01 .16$ & $9^{\circ} 43.87^{\prime}$ & $12^{\circ} 43.87^{\prime}$ & 430 & 6.8 & \\
\hline
\end{tabular}

CTD transects (Fig. 1). Owing to technical problems turbidity data were only collected on the Angolan slope.

\subsubsection{Hydrographic data processing}

The CTD data were processed using the processing software Sea-Bird data SBE 11plus V 5.2 and were visualized using the program Ocean Data View (Schlitzer, 2011; Version 4.7.8).
Hydrographic data recorded by the landers were analyzed and plotted using the program R (R Core Team, 2017). Data from the different instruments (temperature, turbidity, current speed, oxygen concentration, fluorescence) were averaged over a period of $1.5 \mathrm{~h}$ to remove shorter-term trends and occasional spikes. Correlations between variables were assessed by Spearman's rank correlation tests. 
(a)

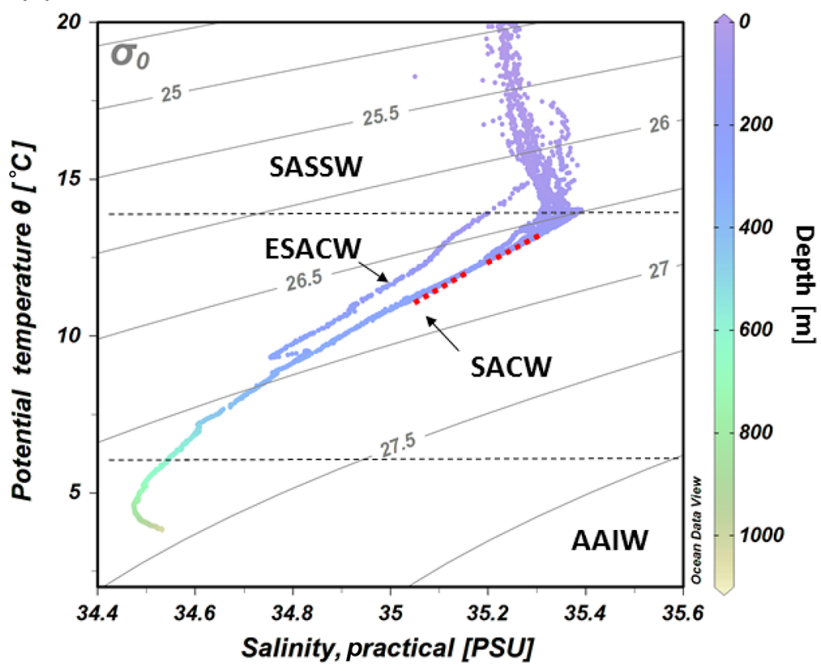

(b)

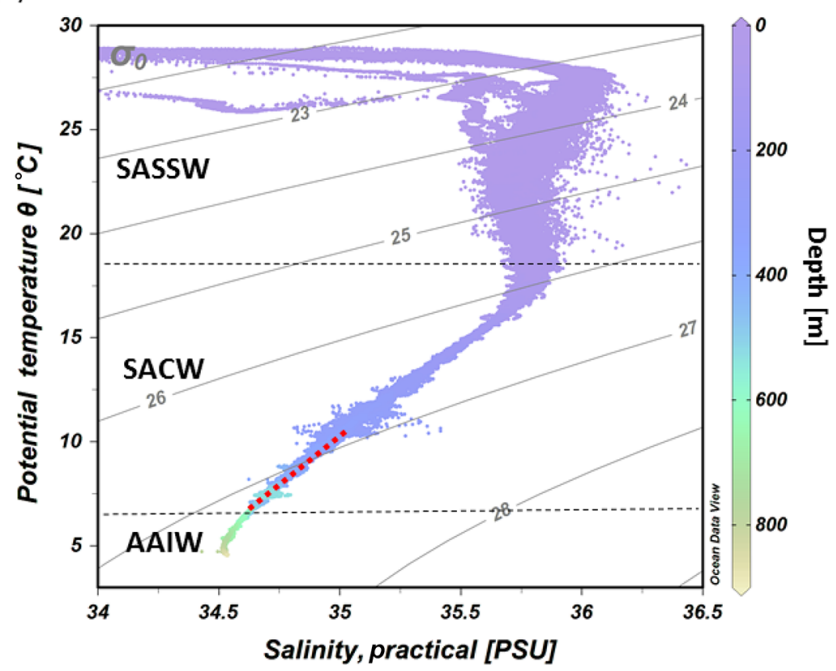

Figure 3. $T-S$ diagrams showing the different water masses being present at the (a) Namibian and (b) Angolan margins: South Atlantic Subtropical Surface Water (SASSW), South Atlantic Central Water (SACW) and Eastern South Atlantic Central water (ESACW), Antarctic Intermediate Water (AAIW) (data plotted using Ocean Data View v.4.7.8; http://odv.awi.de, last access: 12 February 2016; Schlitzer, 2011). Red dotted line indicates the depth range of cold-water coral mound occurrence

\subsubsection{Suspended particulate matter}

Near-bottom suspended particulate organic matter (SPOM) was sampled by means of a phytoplankton sampler (McLane PPS) mounted on the ALBEX lander. The PPS was fitted with $24 \mathrm{GF} / \mathrm{F}$ filters $\left(47 \mathrm{~mm}\right.$ Whatman ${ }^{\mathrm{TM}} \mathrm{GF} / \mathrm{F}$ filters precombusted at $450^{\circ} \mathrm{C}$ ). A maximum of $7.5 \mathrm{~L}$ was pumped over each filter during a $2 \mathrm{~h}$ period, yielding a time series of near-bottom SPOM supply and its variability over a period of $48 \mathrm{~h}$.

\section{$\mathrm{C} / \mathrm{N}$ analysis and isotope measurements}

Filters from the phytoplankton sampler were freeze-dried before further analysis. Half of each filter was used for phytopigment analysis and a 1/4 section of each filter was used for analyzing organic carbon, nitrogen and their stable isotope ratios. The filters used for carbon analysis were decarbonized by vapor of concentrated hydrochloric acid ( $2 \mathrm{M}$ $\mathrm{HCl}$ supra) prior to analyses. Filters were transferred into pressed tin capsules $(12 \mathrm{~mm} \times 5 \mathrm{~mm}$, Elemental Microanalysis), and $\delta^{15} \mathrm{~N}, \delta^{13} \mathrm{C}$ and total weight percent of organic carbon and nitrogen were analyzed by a Delta V Advantage isotope ratio MS coupled online to an Elemental Analyzer (Flash 2000 EA-IRMS) by a ConFlo IV (Thermo Fisher Scientific Inc.). The reference gas was purified atmospheric $\mathrm{N}_{2}$. As standards for $\delta^{13} \mathrm{C}$ benzoic acid and acetanilide were used, for $\delta^{15} \mathrm{~N}$ acetanilide, urea and casein were used. For $\delta^{13} \mathrm{C}$ analysis a high-signal method was used including a $70 \%$ dilution. Values are reported relative to v$\mathrm{pdb}$ and the atmosphere respectively. Precision and accuracy based on replicate analyses and comparison with interna- tional standards for $\delta^{13} \mathrm{C}$ and $\delta^{15} \mathrm{~N}$ was $\pm 0.15 \%$. The $\mathrm{C} / \mathrm{N}$ ratio is based on the weight ratios between total organic carbon (TOC) and N.

\section{Phytopigments}

Phytopigments were measured by reverse-phase highperformance liquid chromatography (RP-HPLC, Waters Acquity UPLC) with a gradient based on the method published by Kraay et al. (1992). For each sample half of a GF/F filter was used and freeze-dried before extraction. Pigments were extracted using $95 \%$ methanol and sonification. All steps were performed in a dark and cooled environment. Pigments were identified by means of their absorption spectrum, fluorescence and the elution time. Identification and quantification took place as described by Tahey et al. (1994). The absorbance peak areas of chlorophyll $a$ were converted into concentrations using conversion factors determined with a certified standard. The $\sum$ phaeopigment / chlorophyll $a$ ratio gives an indication of the degradation status of the organic material, since phaeopigments form as a result of bacterial or autolytic cell lysis and grazing activity (Welschmeyer and Lorenzen, 1985).

\subsubsection{Tidal analysis}

The barotropic (due to the sea level and pressure change) and baroclinic (internal "free waves" propagating along the pycnoclines) tidal signals obtained by the Aquadopp (Nortek ${ }^{\mathrm{TM}}$ ) profiling current meter were analyzed from the bottom pressure and from the horizontal flow components recorded $6 \mathrm{~m}$ above the sea floor, using the T_Tide Harmonic Analysis 
(a)
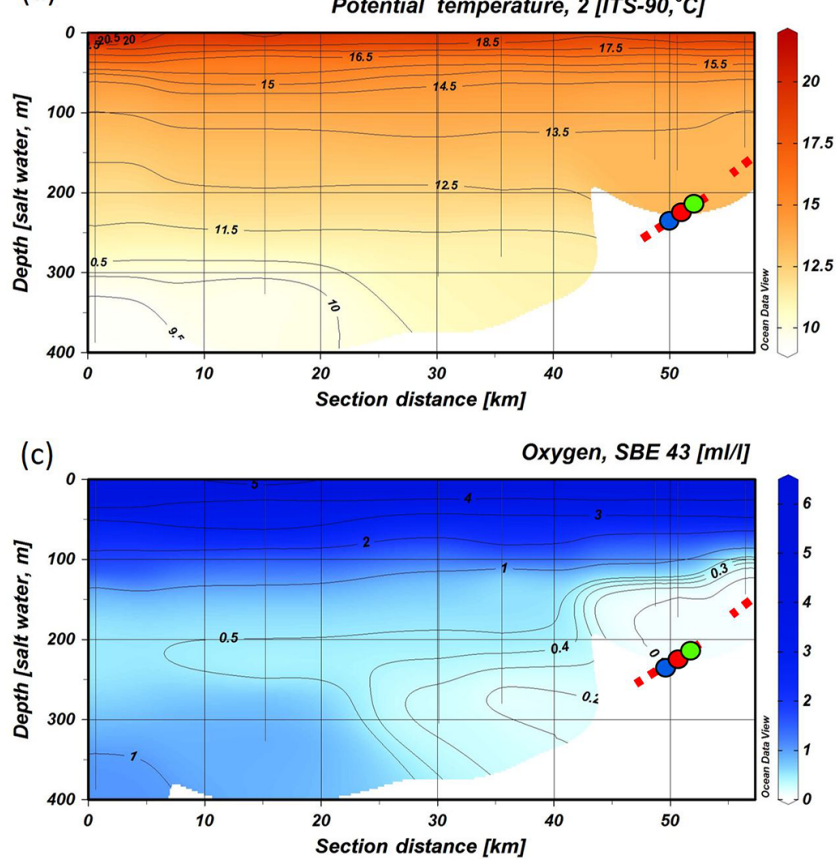

(b)
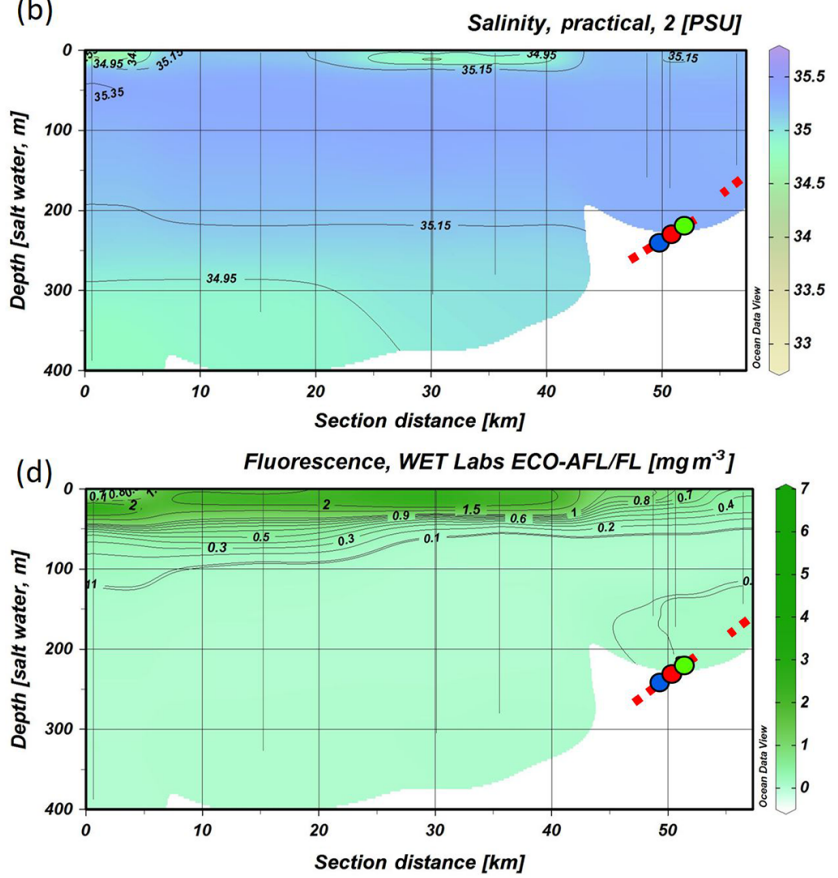

Figure 4. CTD transect across the Namibian margin (see Fig. $1 \mathrm{~b}$ for location). Data are presented for (a) potential temperature $\left({ }^{\circ} \mathrm{C}\right)$, $(\mathbf{b})$ salinity (PSU), (c) dissolved oxygen concentrations $\left(\mathrm{mL} \mathrm{L}^{-1}\right)$, note the pronounced oxygen minimum zone (OMZ) between 100 and $335 \mathrm{~m}$ water depth, and (d) fluorescence $\left(\mathrm{mg} \mathrm{m}^{-3}\right.$ ) (data plotted using Ocean Data View v.4.7.8; http://odv.awi.de, last access: 12 February 2016; Schlitzer, 2011). The occurrence of fossil CWC mounds is indicated by a red dashed line, colored dots indicate bottom lander deployments.

Toolbox (Pawlowicz et al., 2002). The data mean and trends were subtracted from the data before analysis.

\section{Results}

\subsection{Water column properties}

\subsubsection{Namibian margin}

The hydrographic data obtained by CTD measurements along a downslope transect from the surface to $1000 \mathrm{~m}$ water depth revealed distinct changes in temperature and salinity throughout the water column. These are ascribed to the different water masses in the study area (Fig. 3a). In the upper $85 \mathrm{~m}$ of the water column, temperatures were above $14^{\circ} \mathrm{C}$ and salinities $>35.2$, which correspond to South Atlantic Subtropical Surface Water (SASSW). SACW was situated underneath the SASSW and reaches down to about $700 \mathrm{~m}$, characterized by a temperature from 14 to $7^{\circ} \mathrm{C}$ and a salinity from 35.4 to 34.5 (Fig. 3a). A deep CTD cast about $130 \mathrm{~km}$ from the coastline recorded a water mass with the signature of ESACW, having a lower temperature $\left(\Delta 1.3^{\circ} \mathrm{C}\right)$ and lower salinity $(\Delta 0.2)$ than SACW (in $200 \mathrm{~m}$ depth, not included in CTD transects of Fig. 4). Underneath these two central water masses Antarctic Intermediate Water (AAIW) was found with a temperature $<7^{\circ} \mathrm{C}$.
The CTD transect showed decreasing DO (dissolved oxygen) concentration from the surface $\left(6 \mathrm{mLL}^{-1}\right)$ towards a minimum in 150 to $200 \mathrm{~m}$ depth $\left(0 \mathrm{~mL} \mathrm{~L}^{-1}\right)$. Lowest values for DO concentrations were found on the continental margin between 100 and $335 \mathrm{~m}$ water depth. The DO concentrations in this pronounced OMZ ranged from $<1 \mathrm{mLL}^{-1}$ down to

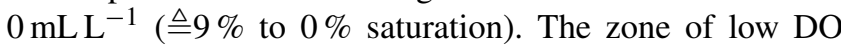
concentrations $\left(<1 \mathrm{mLL}^{-1}\right)$ stretched horizontally over the complete transect from about $50 \mathrm{~km}$ to at least $100 \mathrm{~km}$ offshore (Fig. 4c). The upper boundary of the OMZ was relatively sharp compared to its lower limits and corresponded with the border between SASSW at the surface and SACW below.

Within the OMZ, a small increase in fluorescence $\left(0.2 \mathrm{mg} \mathrm{m}^{-3}\right)$ was recorded, whereas fluorescence was otherwise not traceable below the surface layer (Fig. 4d). Within the surface layer, highest surface fluorescence $\left(>2 \mathrm{mg} \mathrm{m}^{-3}\right)$ was found $\sim 40 \mathrm{~km}$ offshore. Above the center of the OMZ fluorescence reached only $0.4 \mathrm{mg} \mathrm{m}^{-3}$.

\subsubsection{Angolan margin}

The hydrographic data obtained by CTD measurements along a downslope transect from the surface to $800 \mathrm{~m}$ water depth revealed distinct changes in temperature and salinity throughout the water column, related to four different water masses. At the surface a distinct shallow layer $(>20 \mathrm{~m})$ with 

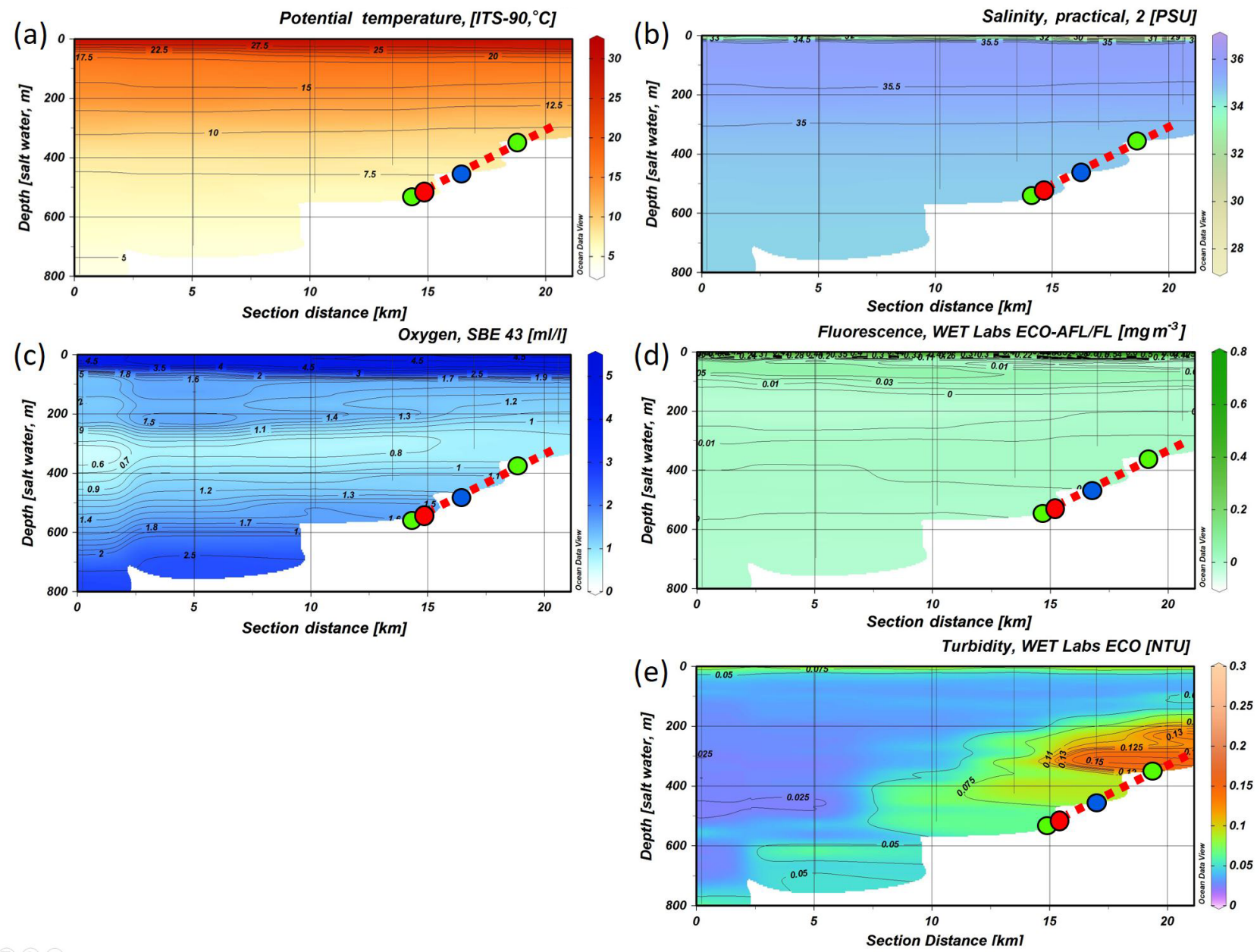

Figure 5. CTD transect across the Angolan margin. Shown are data for (a) potential temperature $\left({ }^{\circ} \mathrm{C}\right)$, (b) salinity (PSU), (c) dissolved oxygen concentration $\left(\mathrm{mL} \mathrm{L}^{-1}\right)$, (d) fluorescence $\left(\mathrm{mg} \mathrm{m}^{-3}\right)$, (e) turbidity (NTU) (data plotted using Ocean Data View v.4.7.8; http://odv.awi.de, last access: 12 February 2016; Schlitzer, 2011). The depth occurrence of CWC mounds is marked by a red, dashed line, and the lander deployments are indicated by colored dots.

a distinctly lower salinity (27.3-35.5) and higher temperature (29.5-27 ${ }^{\circ} \mathrm{C}$, Fig. 3b) was observed. Below the surface layer, SASSW was found down to a depth of $70 \mathrm{~m}$, characterized by a higher salinity (35.8). SACW was observed between 70 and $600 \mathrm{~m}$, showing the expected linear relationship between temperature and salinity. Temperature and salinity decreased from $17.5^{\circ} \mathrm{C}$ and 35.8 to $7^{\circ} \mathrm{C}$ and 34.6. At $700 \mathrm{~m}$ depth AAIW was recorded, characterized by a low salinity $(<34.4)$ and temperature $\left(<7^{\circ} \mathrm{C}\right.$, Fig. 3b).

The CTD transect showed a sharp decrease in the DO concentrations underneath the SASSW from 5 to $<2 \mathrm{mLL}^{-1}$ (Fig. 5). DO concentrations decreased further to a minimum of $0.6 \mathrm{mLL}^{-1}$ at $350 \mathrm{~m}$ and then increased to $>3 \mathrm{~mL} \mathrm{~L}^{-1}$ at $800 \mathrm{~m}$ depth. Lowest DO concentrations were not found at the slope but $70 \mathrm{~km}$ offshore in the center of the zone of reduced DO concentrations between 200 and $450 \mathrm{~m}$ water depth $\left(<1 \mathrm{mLL}^{-1}\right)$. Compared to the Namibian margin (see Fig. 4), the hypoxic layer was situated further offshore, slightly deeper, and overall DO concentrations were higher (compare Fig. 4c). Also, the boundaries of the hypoxic zone were not as sharp. Fluorescence near the sea surface was generally low (around 0.2 with small maxima of $0.78 \mathrm{mg} \mathrm{m}^{-3}$ ) and not detectable deeper than $150 \mathrm{~m}$ depth. A distinct zone of enhanced turbidity was observed on the continental margin between 200 and $350 \mathrm{~m}$ water depth.

\subsection{Near-bottom environmental data}

\subsubsection{Namibian margin}

Bottom temperature ranged from 11.8 to $13.2^{\circ} \mathrm{C}$ during the deployment of the ALBEX lander (Table 2, Fig. 6), showing oscillating fluctuations with a maximum semidiurnal ( $\Delta T \sim 6 \mathrm{~h}$ ) change of $\sim \Delta 1^{\circ} \mathrm{C}$ (on 9 January 2016). The DO concentrations fluctuated between 0 and $0.15 \mathrm{mLL}^{-1}$ 
and were negatively correlated with temperature $(r=-0.39$, $p<0.01)$. Fluorescence ranged from 42 to 45 NTU during the deployment and was positively correlated with temperature $(r=0.38, p<0.01)$. Hence, both temperature and fluorescence were negatively correlated with DO concentrations $(r=-0.39, p<0.01)$ and turbidity (optical backscatter, $r=-0.35, p<0.01)$. Turbidity was low until it increased markedly during the second half of the deployment. During this period on the 6 January, wind speed increased from $10 \mathrm{~m} \mathrm{~s}^{-1}$ to a maximum of $17 \mathrm{~m} \mathrm{~s}^{-1}$ and remained high for the next 6 . The wind direction changed from counterclockwise cyclonic rotation towards alongshore winds. During the strong wind period, colder water (correlation between wind speed and water temperature, $r=-0.55, p<0.01)$ with a higher turbidity (correlation of wind speed and turbidity, $r=0.42, p<0.01)$ and on average higher DO concentrations was present. The SLM lander recorded an average $\mathrm{pH}$ of 8.01 .

Maximum current speeds measured during the deployment period were $0.21 \mathrm{~m} \mathrm{~s}^{-1}$, with average current speeds of $0.09 \mathrm{~m} \mathrm{~s}^{-1}$ (Table 2). The tidal cycle explained $>80 \%$ of the pressure fluctuations (Table 3 ), with a semidiurnal signal, M2 (principal lunar semidiurnal), generating an amplitude of $>0.35 \mathrm{dbar}$ and thus being the most important constituent. Before the 6 January, the current direction oscillated between SW and SE after which it changed to a dominant northerly current direction (Fig. 6).

The observed fluctuations in bottom water temperature at the deployment site imply a vertical tidal movement of around $70 \mathrm{~m}$. This was estimated by comparing the temperature change recorded by the lander to the respective temperature-depth gradient based on water column measurements (CTD site GeoB20553, $12.58^{\circ} \mathrm{C}$ at $245 \mathrm{~m}, 12.93{ }^{\circ} \mathrm{C}$ at $179 \mathrm{~m})$. Due to these vertical tidal movements, the oxygendepleted water from the core of the OMZ is regularly being replaced with somewhat colder and slightly more oxygenated water ( $\Delta$ up to $0.2 \mathrm{~mL} \mathrm{~L}^{-1}$ ).

\subsubsection{Angolan margin}

Mean bottom water temperatures were $6.73^{\circ} \mathrm{C}$ at the deeper site $(530 \mathrm{~m})$ and $10.06^{\circ} \mathrm{C}$ at the shallower site $(340 \mathrm{~m}$, Fig. 7 , Table 2). The maximum semidiurnal $(\Delta T \sim 6 \mathrm{~h}$ ) temperature change was $\Delta 1.60^{\circ} \mathrm{C}$ at the deepest site and $\Delta 2.4^{\circ} \mathrm{C}$ at the shallow site (Fig. 7). DO concentrations at the deep site were a factor of 2 higher than those at the shallow site, i.e., $0.9-1.5$ vs. $0.5-0.8 \mathrm{~mL} \mathrm{~L}^{-1}$ respectively $\triangleq$ range between $4 \%$ and $14 \%$ saturation of both sites), whereas the range of diurnal fluctuations was much smaller compared to the shallow site. DO concentrations were negatively correlated with temperature at the deep site $(r=-0.99, p<0.01)$, while positively correlated at the shallow site $(r=0.91, p<0.01)$. Fluorescence was low during both deployments and showed only small fluctuations, being slightly higher at the shallow site (between 38.5 and $41.5 \mathrm{NTU}$ at both sites). Current speeds were relatively high (between 0 and $0.3 \mathrm{~m} \mathrm{~s}^{-1}$, average $0.1 \mathrm{~m}$ $\mathrm{s}^{-1}$ ) and positively correlated with temperature at the shallow site $(r=0.31, p<0.01)$ and negatively correlated at the deep site $(r=-0.22, p<0.01)$. Analysis of the tidal cycle showed that it explained $29.8 \%-54.9 \%$ of the horizontal current fluctuations. The M2 amplitude was $0.06-0.09 \mathrm{~s}^{-1}$ and was the most important signal (Table 3). A decrease in turbidity was observed during the deployment at the shallow station. This station was located directly below the turbidity maximum between 200 and $350 \mathrm{~m}$ depth as observed in the CTD transect (Fig. 5). In contrast, a relative constant and low turbidity was observed for the deep deployment. Turbidity during both deployments was positively correlated to DO concentrations $(r=0.47, p<0.01$, shallow deployment and $r=0.50, p<0.01$, deep deployment). The SLM lander recorded an average $\mathrm{pH}$ of 8.12.

The short-term temperature fluctuations imply a vertical tidal movement of around $130 \mathrm{~m}\left(12.9-9.1^{\circ} \mathrm{C}\right.$ measured by lander, $\triangleq 218-349 \mathrm{~m}$ depth in CTD above lander at station GeoB20966).

\subsection{Suspended particulate matter}

\subsubsection{Namibian margin}

The nitrogen $(\mathrm{N})$ concentration of the SPOM measured on the filters of the McLane pump fluctuated between 0.25 and $0.45 \mathrm{mg} \mathrm{L}^{-1}$ (Fig. 8). The highest $\mathrm{N}$ concentration corresponded with a peak in turbidity $(r=0.42, p<0.01)$. The $\delta^{15} \mathrm{~N}$ values of the lander time series fluctuated between 5.1 and 6.9 with an average value of $5.7 \%$. Total organic carbon (TOC) showed a similar pattern as nitrogen, with relative concentrations ranging between 1.8 and $3.5 \mathrm{mg} \mathrm{L}^{-1}$. The $\delta^{13} \mathrm{C}$ value of the TOC increased during the surveyed time period from $-22.39 \%$ o to $-21.24 \%$ with an average of $-21.7 \%$ (Fig. 8a). The $\mathrm{C} / \mathrm{N}$ ratio ranged from $8.5-6.8$ and was on average 7.4 (Fig. 8b). During periods of low temperature and more turbid conditions TOC and $\mathrm{N}$ as well as the $\delta^{13} \mathrm{C}$ values of the SPOM were higher.

Chlorophyll $a$ concentrations of SPOM were on average $0.042 \mu \mathrm{g} \mathrm{L}^{-1}$ and correlated with the record of the fluorescence $(r=0.43, p=0.04)$. A 6 times higher amount of chlorophyll $a$ degradation products was found during the lander deployment $\left(0.248 \mu \mathrm{g} \mathrm{L}^{-1}\right)$ compared to the amount of chlorophyll $a$, giving a $\sum$ phaeopigment / chlorophyll $a$ ratio of 6.5 (not shown). Additionally, carotenoids (0.08$\left.0.12 \mu \mathrm{g} \mathrm{L}^{-1}\right)$ and fucoxanthin $\left(0.22 \mu \mathrm{g} \mathrm{L}{ }^{-1}\right)$, which are common in diatoms, were major components of the pigment fraction. Zeaxanthin, indicating the presence of prokaryotic cyanobacteria, was only observed in small quantities $\left(0.066 \mu \mathrm{g} \mathrm{L}^{-1}\right)$. 
Table 2. Environmental properties at the Namibian and Angolan margins.

\begin{tabular}{lll}
\hline & Namibia & Angola \\
\hline Temperature $\left({ }^{\circ} \mathrm{C}\right)$ & $11.8-13.2$ & $6.73-12.9$ \\
DO concentration $\left(\mathrm{mL} \mathrm{L}^{-1}\right)$ & $0-0.15$ & $0.5-1.5$ \\
Fluorescence $(\mathrm{NTU})$ & $42-45$ & $38.5-41.5$ \\
Current speed max. $\left(\mathrm{m} \mathrm{s}^{-1}\right)$ & 0.21 & 0.3 \\
Current speed average $\left(\mathrm{m} \mathrm{s}^{-1}\right)$ & 0.09 & 0.1 \\
Tidal cycle & Semidiurnal & Semidiurnal \\
& $\left(0.37 \mathrm{dbar}, 3 \mathrm{~cm} \mathrm{~s}^{-1}\right)$ & $\left(0.6 \mathrm{dbar}, 8.2 \mathrm{~cm} \mathrm{~s}^{-1}\right)$ \\
Average $\mathrm{pH}$ & 8.01 & 8.12 \\
\hline
\end{tabular}

Table 3. Tidal analysis of the ALBEX lander from $6 \mathrm{~m}$ above the sea floor. Depth, mean current speed, mean current direction, tidal prediction of pressure fluctuations, two most important harmonics with amplitude, tidal prediction of horizontal current field, two most important harmonics with semi-major axes' amplitudes.

\begin{tabular}{|c|c|c|c|c|c|c|c|c|}
\hline & $\begin{array}{l}\text { Station } \\
\text { no. (GeoB ID) }\end{array}$ & $\begin{array}{r}\text { Depth } \\
(\mathrm{m})\end{array}$ & $\begin{array}{r}\text { Mean current } \\
\text { speed }\left(\mathrm{cm} \mathrm{s}^{-1}\right)\end{array}$ & $\begin{array}{r}\text { Current } \\
\text { direction }\left(^{\circ}\right)\end{array}$ & $\begin{array}{r}\text { Tides } \\
(\%)(p)\end{array}$ & $\begin{array}{l}\text { Const. } \\
\text { (dbar) }\end{array}$ & $\begin{array}{l}\text { Tides } \\
(\%)(u)\end{array}$ & $\begin{array}{l}\text { Const. } \\
\left(\mathrm{cm} \mathrm{s}^{-1}\right)\end{array}$ \\
\hline Namibia & $20507-1$ & 430 & 9.34 & 221.6 & 81.8 & M2: 0.37 & 10.5 & $\begin{array}{l}\text { M2: } 3.1 \\
\text { M3: } 0.8\end{array}$ \\
\hline \multirow[t]{2}{*}{ Angola } & 20921-1 & 340 & 9.96 & 247.9 & 91.6 & $\begin{array}{l}\text { M2: } 0.59 \\
\text { M3: } 0.04\end{array}$ & 36 & $\begin{array}{l}\text { M2: } 7.8 \\
\text { M8: } 0.7\end{array}$ \\
\hline & 20940-1 & 530 & 8.92 & 275.6 & 86.8 & $\begin{array}{l}\text { M2: } 0.60 \\
\text { M8: } 0.02\end{array}$ & 50.9 & $\begin{array}{l}\text { M2: } 8.6 \\
\text { M3: } 3.7\end{array}$ \\
\hline
\end{tabular}

\subsubsection{Angolan margin}

In general TOC and N concentrations of SPOM were higher at the shallow site compared to the deep site. Nitrogen concentrations varied around $0.14 \mathrm{mg} \mathrm{L}^{-1}$ at $340 \mathrm{~m}$ and around $0.1 \mathrm{mg} \mathrm{L}^{-1}$ at $530 \mathrm{~m}$ depth (Fig. 8b). The $\delta^{15} \mathrm{~N}$ values at the shallow site ranged from $1.6 \%$ to $6.2 \%$ (3.7\%o average) and were even lower deeper in the water column, viz. range $0.3-3.7 \%$ with an average of $1.4 \%$. The TOC concentrations were on average $1.43 \mathrm{mg} \mathrm{L}^{-1}$ at $340 \mathrm{~m}$ and $0.9 \mathrm{mg} \mathrm{L}^{-1}$ at $530 \mathrm{~m}$, with corresponding $\delta^{13} \mathrm{C}$ values ranging between -23.0 and -24.2 (average of $-23.6 \%$ ) at the shallow, and between -22.9 and -23.9 (average $-23.4 \%$ ) at the deep site.

The chlorophyll $a$ concentrations of the SPOM collected by the McLane pump varied between 0.1 and $0.02 \mu \mathrm{g} \mathrm{L}^{-1}$, with average $\sum$ phaeopigment / chlorophyll $a$ ratios of 2.6 and 0.5 at the shallow and deep sites, respectively. Phytopigments recorded by the shallow deployment included $0.3 \mu \mathrm{g} \mathrm{L}^{-1}$ of fucoxanthin, while at the deep site only a concentration of $0.1 \mu \mathrm{g} \mathrm{L}^{-1}$ was found. No zeaxanthin was recorded in the pigment fraction.

\section{Discussion}

Even though the ecological-niche factor analyses of Davies et al. (2008) and Davies and Guinotte (2011) predict $L$. pertusa to be absent along the oxygen-limited southwestern African margin, CWC mounds with two distinct benthic ecosystems were found. The coral mounds on the Namibian shelf host no living CWCs; instead the dead coral framework covering the mounds was overgrown with fauna dominated by bryozoans and sponges. Along the slope of the Angolan margin an extended coral mound area with thriving CWC communities was encountered. It is probably that differences in present-day environmental conditions between the areas influence the faunal assemblages inhabiting them. The potential impact of the key environmental factors will be discussed below.

\subsection{Short-term vs. long-term variations in environmental properties}

On the Namibian margin, seasonality has a major impact on local mid-depth oxygen concentration due to the periodically varying influence of the Angola current and its associated low DO concentrations (Chapman and Shannon, 1987). The lowest DO concentration is expected from February to May when SACW is the dominating water mass on the Namibian margin and the contribution of ESACW is smaller (Mohrholz et al., 2008). Due to this seasonal pattern, the DO concentrations measured in this study (January; Fig. 4) probably do not represent minimum concentrations, which are expected to occur in the following months, but nevertheless give a 

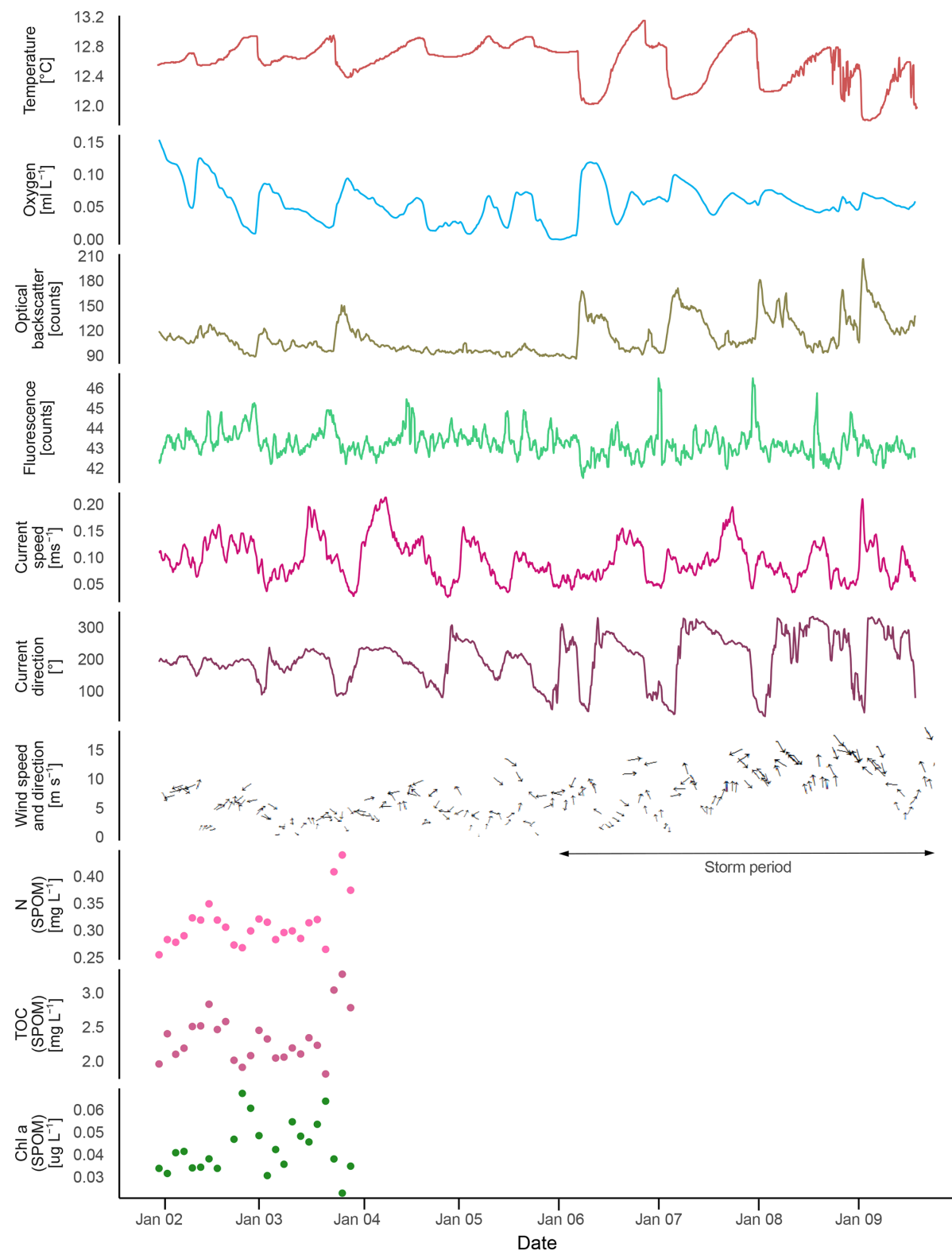

Figure 6. Data recorded by the ALBEX lander $(210 \mathrm{~m})$ at the Namibian margin in January 2016. Shown are data for temperature $\left({ }^{\circ} \mathrm{C}\right.$; red), dissolved oxygen concentrations ( $\mathrm{mLL}^{-1}$; blue), optical backscatter (turbidity; moss green), fluorescence (counts per second; green), current speed ( $\mathrm{m} \mathrm{s}^{-1}$; pink), current direction ( ${ }^{\circ}: 0-360^{\circ}$; dark red) as well as nitrogen $\left(\mathrm{mg} \mathrm{L}^{-1}\right.$; pink dots), carbon (mg L ${ }^{-1}$; purple dots), and chlorophyll $a$ concentration ( $\mu \mathrm{g} \mathrm{L}^{-1}$; green dots) of SPOM collected during the first $48 \mathrm{~h}$ by the McLane pump. These data are supplemented by wind speed and direction (small black arrows) recorded concurrently to the lander deployment by ship bound devices. Note that current directions changed from a generally south-poleward to an equatorward direction when wind speed exceeded $10 \mathrm{~m} \mathrm{~s}^{-1}$ (stormy period indicated by black arrow).

valuable impression about the extent of the OMZ (February to May; Mohrholz et al., 2014). Interestingly, we captured a flow reversal after 6 January from a southward to an equatorward current direction during high wind conditions on the Namibian margin (Fig. 6), leading to an intrusion of ESACW with higher DO concentrations $\left(\Delta 0.007 \mathrm{mLL}^{-1}\right.$ on average) and lower temperatures $\left(\Delta 0.23^{\circ} \mathrm{C}\right.$ on average, Fig. 5) than the SACW. This led to a temporal increase in the DO concentrations. This shows that variations in the local flow field have the capability to change water properties on relatively short time scales, which might provide an analogue to the water mass variability related to the different seasons (Mohrholz et al., 2008). Such relaxations are possibly important for the survival of the abundant benthic fauna present on the relict coral mounds (Gibson et al., 2003). Other seasonal changes, like riverine outflow, do not have decisive impacts 


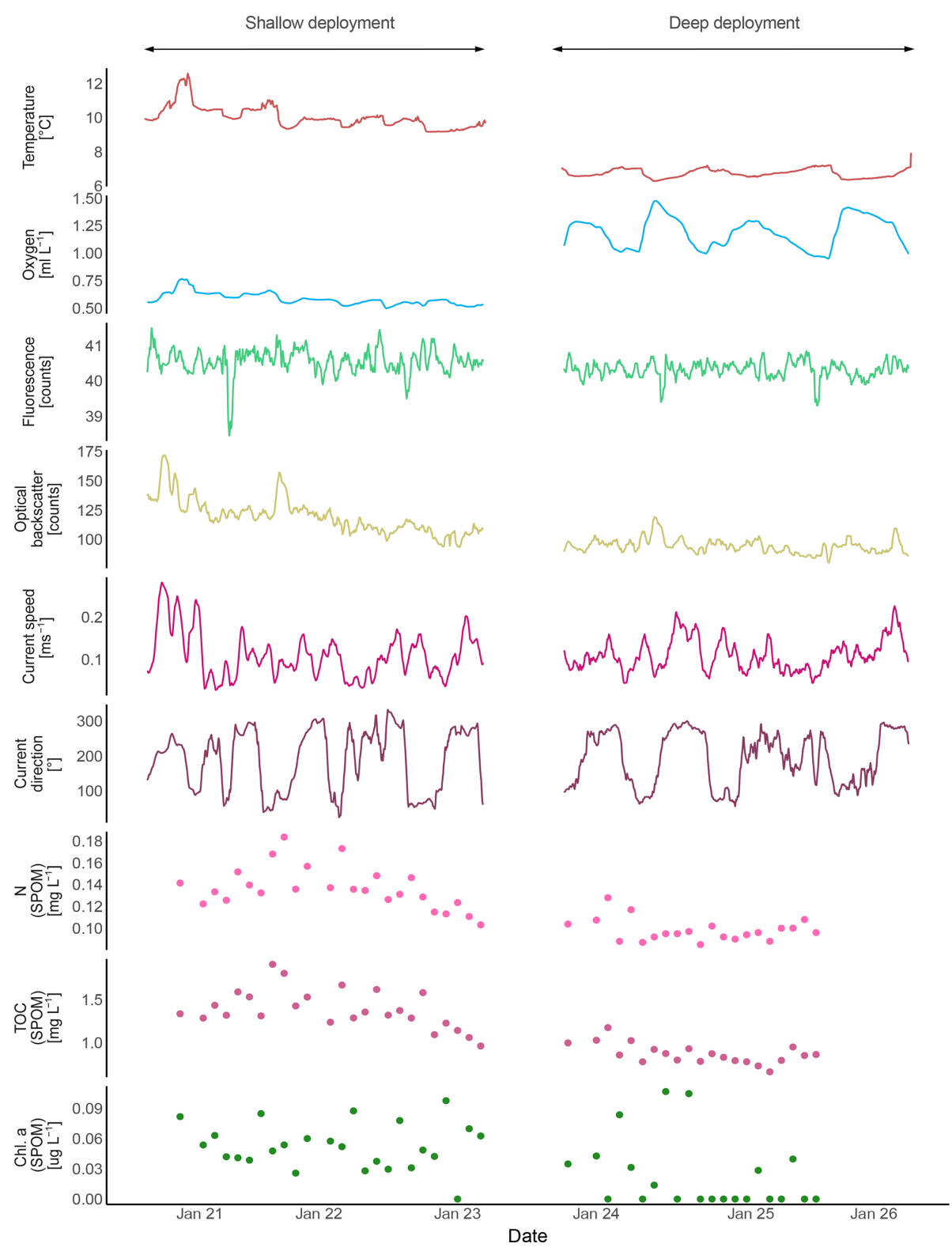

Figure 7. Lander data (ALBEX) recorded during at the shallow ( $\sim 340 \mathrm{~m}$ water depth $)$ and deep sites $(\sim 530 \mathrm{~m}$ water depth) off Angola (January 2016). Shown are temperature $\left({ }^{\circ} \mathrm{C}\right.$; red), dissolved oxygen concentration $\left(\mathrm{mLL}^{-1}\right.$; blue), fluorescence (counts per second; green), optical backscatter (turbidity; yellow), current speed $\left(\mathrm{m} \mathrm{s}^{-1}\right.$; pink) and current direction $\left({ }^{\circ}: 0-360^{\circ}\right.$; purple) as well as nitrogen (mg $\mathrm{L}^{-1}$; pink dots), carbon ( $\mathrm{mg} \mathrm{L}^{-1}$; purple dots), and chlorophyll $a$ concentration $\left(\mu \mathrm{g} \mathrm{L}^{-1}\right.$, green dots) of SPOM collected during the both deployments by the McLane pump.

on the ecosystem since only relatively small rivers discharge from the Namibian margin. This is also reflected by the dominant marine isotopic signature of the isotopic ratios of $\delta^{15} \mathrm{~N}$ and $\delta^{13} \mathrm{C}$ of the SPOM at the mound areas (Fig. 8, cf. Tyrrell and Lucas, 2002).

Flow reversals were not observed during the lander deployments on the Angolan margin, where winds are reported to be weak throughout the year providing more stable conditions (Shannon, 2001). Instead river outflow seems to exert a strong influence on the DO concentrations on the Angolan margin. The runoff of the Cuanza and Congo river reach their seasonal maximum in December and January (Kopte et al., 2017), intensifying upper water column stratification. This stratification is restricting vertical mixing and thereby limits ventilation of the oxygen-depleted subsurface water masses. In addition rivers transport terrestrial organic matter to the margin, which is reflected by the isotopic signals of the SPOM (-1\%o to $3 \%$; Montoya, 2007) which is well below the average isotopic ratio of the marine waters of $5.5 \%$ (Meisel et al., 2011). Also $\delta^{13} \mathrm{C}$ values are in line 

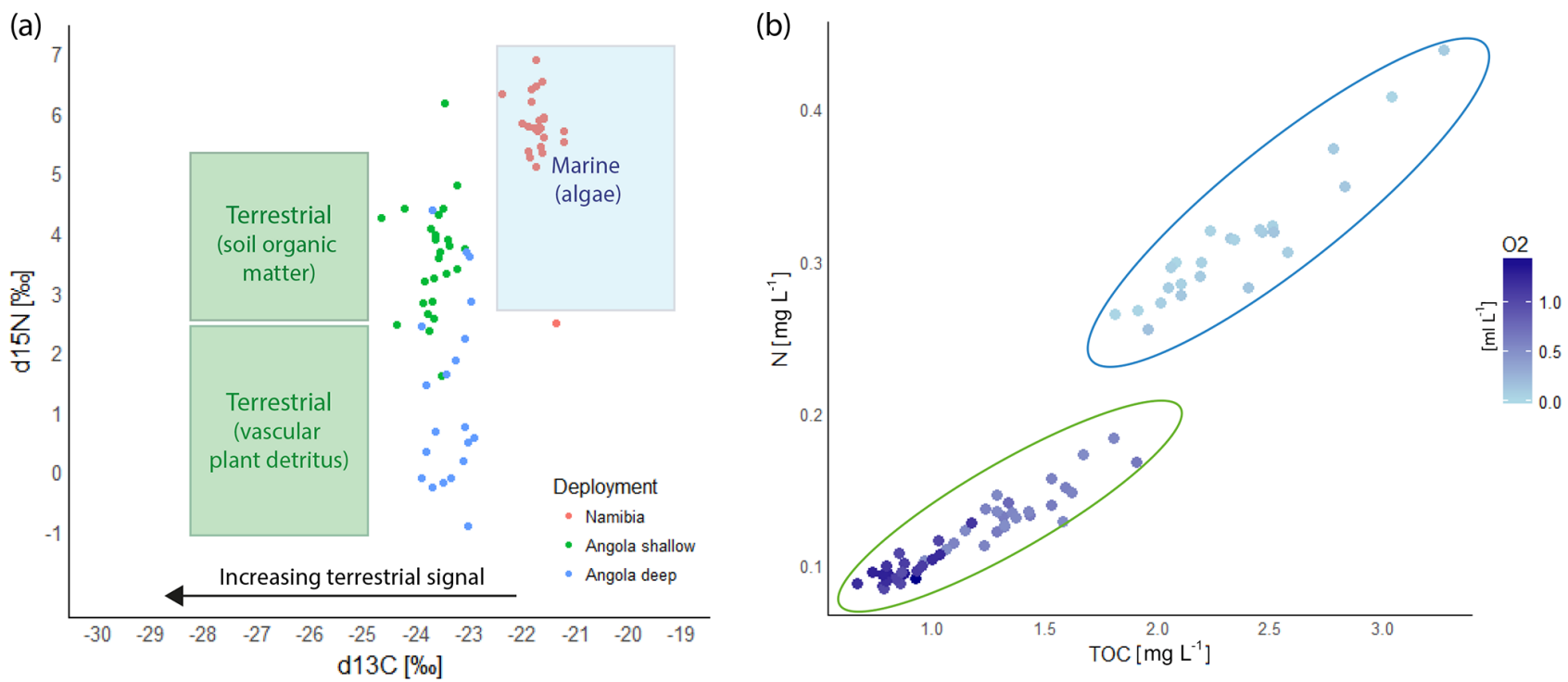

Figure 8. Composite records of SPOM collected by the McLane pump of the ALBEX lander at the Namibian and Angolan margins during all three deployments. (a) $\delta^{15} \mathrm{~N}$ and $\delta^{13} \mathrm{C}$ isotopic values at the Namibian (red dots) and Angolan (blue and green dots) margins. Indicated by the square boxes are common isotopic values of terrestrial and marine organic matter (Boutton, 1991; Holmes et al., 1997; Sigman et al., 2009). The relative contribution of terrestrial material (green boxes) is increasing with a more negative $\delta^{13} \mathrm{C}$ value. (b) Total organic carbon (TOC) and nitrogen $(\mathrm{N})$ concentration of the SPOM. Values of the Namibian margin are marked by a blue circle $(\mathrm{C} / \mathrm{N}$ ratio $=7.8)$, values of the Angolan margin are marked by a green circle $(\mathrm{C} / \mathrm{N}$ ratio $=9.6)$. Dissolved oxygen concentrations are included to show the higher nutrient concentrations in less oxygenated water.

with the $\delta^{13} \mathrm{C}$ values of terrestrial matter which is on average $-27 \%$ in this area (Boutton, 1991; Mariotti et al., 1991). The $\mathrm{C} / \mathrm{N}$ ratio of SPOM is higher compared to material from the Namibian margin, also confirming admixing of terrestrial matter (Perdue and Koprivnjak, 2007). This terrestrial matter contains suitable food sources as well as less suitable food sources, like carbon-rich polymeric material (cellulose, hemicellulose and lignin), which cannot easily be taken up by marine organisms (Hedges and Oades, 1997). The combined effects of decreased vertical mixing and additional input of organic matter potentially result in the lowest DO concentrations of the year during the investigated time period (January), since the highest river outflow and therefore strongest stratification is expected during this period.

\subsection{Main stressors - oxygen and temperature}

Environmental conditions marked by severe hypoxia and temporal anoxia $\left(<0.17 \mathrm{~mL} \mathrm{~L}^{-1}\right)$ likely explain the presentday absence of living CWCs along the Namibian margin. During the measurement period the DO concentrations off Namibia were considerably lower than the thus far recorded minimum concentrations near living CWCs $\left(1-1.3 \mathrm{~mL} \mathrm{~L}^{-1}\right)$, which were found off Mauritania where only isolated living CWCs are found (Ramos et al., 2017). Age dating of the Namibian fossil coral framework showed that CWCs disappeared about $5 \mathrm{ka}$ which coincides with an intensification in upwelling and therefore most likely a decline of
DO concentrations (Tamborrino et al., 2019), supporting the assumption that the low DO concentrations are responsible for the demise of CWCs on the Namibian margin. Although no living corals were observed on the Namibian coral mounds, we observed a dense living community dominated by sponges and bryozoans (Hebbeln et al., 2017). Several sponge species have been reported to survive at extremely low DO concentrations within OMZs. For instance, along the lower boundary of the Peruvian OMZ, sponges were found at DO concentrations as low as $0.06-0.18 \mathrm{~mL} \mathrm{~L}^{-1}$ (Mosch et al., 2012). Mills et al. (2018) recently found a sponge (Tethya wilhelma) to be physiologically almost insensitive to oxygen stress and respires aerobically under low DO concentrations $\left(0.02 \mathrm{~mL} \mathrm{~L}^{-1}\right)$. Sponges can potentially stop their metabolic activity during unfavorable conditions and restart their metabolism when some oxygen becomes available, for instance during diurnal irrigation of water with somewhat higher DO concentrations. The existence of a living sponge community off Namibia might therefore be explained by the diurnal tides occasionally flushing the sponges with more oxic water, enabling them to metabolize, when food availability is highest (Fig. 6). Increased biomass and abundances in these temporary hypoxic-anoxic transition zones were already observed for macro- and megafauna in other OMZs and is referred to as the "edge effect" (Mullins et al., 1985; Levin et al., 1991; Sanders, 1969). It is very likely that this mechanism plays a role for the benthic communities on the Namibian as well as the Angolan margin. 
(a)

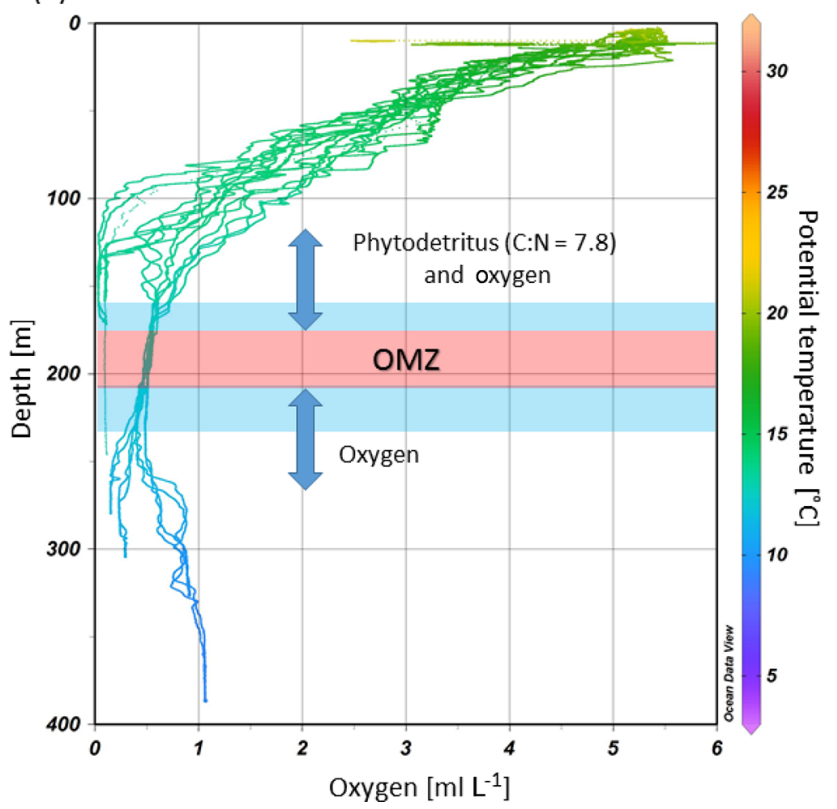

(b)

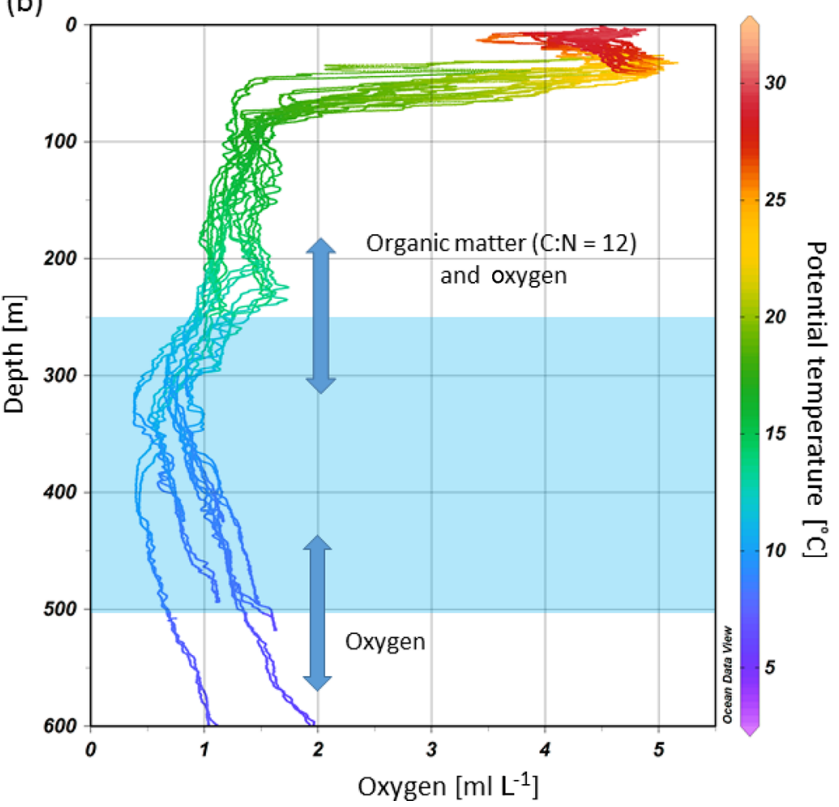

Figure 9. Depth range of cold-water coral mound occurrences (blue shaded areas) at the (a) Namibian and (b) Angolan margins in relation to the dissolved oxygen concentrations and potential temperature. Diurnal tides are delivering mainly phytodetritus (shown in a) and organic matter from the benthic nepheloid layer (shown in b) as well as oxygen from above and from below to the mound sites (indicated by blue arrows, the lengths of which indicate the tidal ranges).

Along the Angolan margin, low oxygen concentrations apparently do not restrict the proliferation of thriving CWC reefs even though DO concentrations are considered hypoxic $\left(0.5-1.5 \mathrm{mLL}^{-1}\right)$. The DO concentrations measured off Angola are well below the lower DO concentration limits for L. pertusa based on laboratory experiments and earlier field observations (Schroeder, 2002; Brooke and Ross, 2014). The DO concentrations encountered at the shallow mound sites $\left(<0.8 \mathrm{~mL} \mathrm{~L}^{-1}\right)$ are even below the so far lowest limits known for single CWC colonies from the Mauritanian margin (Ramos et al., 2017b). Since in the present study measured DO concentrations were even lower than the earlier established lower limits, this could suggest a much higher tolerance of $L$. pertusa to oxygen levels as low as $0.5 \mathrm{~mL} \mathrm{~L}^{-1}$ at least in a limited time period $\left(4 \% \mathrm{O}_{2}\right.$ saturation).

In addition to oxygen stress, heat stress is expected to put additional pressure on CWCs. Temperatures at the CWC mounds off Angola ranged from 6.4 to $12.6^{\circ} \mathrm{C}$, with the upper limit being close to reported maximum temperatures $\left(\sim 12-14.9^{\circ} \mathrm{C}\right.$; Davies and Guinotte 2011$)$ and are hence expected to impair the ability of CWCs to form mounds (see Wienberg and Titschack 2017). The CWCs were also occurring outside of the expected density envelope of 27.35$27.65 \mathrm{~kg} \mathrm{~m}^{-3}$ in densities well below $27 \mathrm{~kg} \mathrm{~m}^{-3}$ (Fig. 3, Dullo et al., 2008). In most aquatic invertebrates, respiration rates roughly double with every $10^{\circ} \mathrm{C}$ increase $\left(Q_{10}\right.$ temperature coefficient $=2-3$, e.g., Coma, 2002), which at the same time doubles energy demand. Dodds et al. (2007) found a doubling of the respiration rate of $L$. pertusa with an increase at ambient temperature of only $2^{\circ} \mathrm{C}$ (viz. $Q_{10}=7-8$ ). This would limit the survival of $L$. pertusa at high temperatures to areas where the increased demand in energy (due to increased respiration) can be compensated by high food availability. Higher respiration rates also imply that enough oxygen needs to be available for the increased respiration. However this creates a negative feedback, since with increased food availability and higher temperatures the oxygen concentration will decrease due to bacterial decomposition of organic substances.

Survival of $L$. pertusa under hypoxic conditions along the shallow Angolan CWC areas is probably positively influenced by the fact that periods of highest temperatures coincide with highest DO concentrations during the tidal cycle. Probably here the increase of one stressor is compensated by a reduction of another stressor. On the Namibian margin and the deeper Angolan mound sites the opposite pattern was found, with highest temperatures during lowest DO concentrations. However, at the deeper Angolan mound sites DO concentrations are higher and temperatures more within a suitable range compared to the shallow sites (0.9$1.5 \mathrm{~mL} \mathrm{~L}^{-1}, 6.4-8{ }^{\circ} \mathrm{C}$, Fig. 7). Additionally it was shown by ex situ experiments that $L$. pertusa is able to survive periods of hypoxic conditions similar to those found along the Angolan margin for several days, which could be crucial in periods of most adverse conditions (Dodds et al., 2007). 


\subsection{Food supply}

As mentioned above, environmental stresses like high temperature or low DO concentration result in a loss of energy (Odum, 1971; Sokolova et al., 2012), which needs to be balanced by an increased energy (food) availability. Food availability therefore plays a significant role for faunal abundance under hypoxia or unfavorable temperatures (Diaz and Rosenberg, 1995). Above, we argued that survival of sponges and bryozoans on the relict mounds off Namibia and of CWCs, and their associated fauna at the Angolan margin, may be partly due to a high input of high-quality organic matter, compensating oxygen and thermal stresses. The importance of the food availability for CWCs was already suggested by Eisele et al. (2011), who mechanistically linked CWC mound growth periods with enhanced surface water productivity and hence organic matter supply. Here we found evidence for high quality and quantity of SPOM in both areas indicated by high TOC and N concentrations (Figs. 6 and 7) in combination with a low $\mathrm{C} / \mathrm{N}$ ratio (Fig. 8), a low isotopic signature of $\delta^{15} \mathrm{~N}$ and only slightly degraded pigments.

The Namibian margin is known for its upwelling cells, where phytoplankton growth is fueled by nutrients from deeper water layers producing high amounts of phytodetritus (Chapman and Shannon, 1985), which subsequently sinks down to the relict mounds on the slope. Benthic communities on the mounds off Namibia occur at relatively shallow depths, hence downward transport of SPOM from the surface waters is rapid and time for decomposition of the sinking particles in the water column is limited. The higher turbidity during lower current speeds provides additional evidence that the material settling from the surface is not transported away with the strong currents (Fig. 6).

At the Angolan coral mounds, SPOM appeared to have a signature corresponding to higher quality organic matter compared to the SPOM off Namibia. The phytopigments were less degraded and the $\delta^{15} \mathrm{~N}$, TOC and $\mathrm{N}$ concentrations of the SPOM were lower. However, here lower $\delta^{15} \mathrm{~N}$ and a higher $\sum$ phaeopigment / chlorophyll $a$ ratio are likely connected to a mixture with terrestrial OM input, which might constitute a less suitable food source for CWCs (Hedges and Oades, 1997). On the other hand, the riverine input delivers dissolved nutrients, which can support the growth of phytoplankton, indirectly influencing food supply (Kiriakoulakis et al., 2007; Mienis et al., 2012). Moreover, the variations in food quality at the shallow Angolan reefs, which were relatively small during this study, did not seem to be related to the presence of other environmental stressors. At the Angolan margin we see a rather constant availability of SPOM. The slightly higher turbidity during periods of highest DO concentrations (Fig. 7) suggests that the SPOM on the Angolan margin originates from the bottom nepheloid layer on the margin directly above the CWC mounds (Fig. 5e), which may represent a constant reservoir of fresh SPOM.
This reservoir is probably fueled by directly sinking as well as advected organic matter from the surface ocean.

\subsection{Tidal currents}

The semidiurnal tidal currents observed probably play a major role in the survival of benthic fauna on the SW African margin. On the Namibian margin, internal waves deliver oxygen from the surface and deeper waters to the OMZ and thereby enable benthic fauna on the fossil coral framework to survive in hypoxic conditions (Fig. 9a). At the same time these currents are probably responsible for the delivery of fresh SPOM from the surface productive zone to the communities on the margin, since they promote mixing between the water masses as well as they vertically displace the different water layers.

On the Angolan margin, internal tides produce slightly faster currents and vertical excursions of up to $130 \mathrm{~m}$ which are twice as high as those on the Namibian margin. Similar to the Namibian margin, these tidal excursions deliver oxygen from shallower and deeper waters to the mound zone and thereby deliver water with more suitable characteristics over the whole extent of the parts of the OMZ which otherwise may be unsuitable for CWCs (Fig. 9b). Internal tides are also responsible for the formation of a bottom nepheloid layer at 200-350 m depth (Fig. 5e). This layer is formed by trapping of organic matter as well as bottom erosion due to turbulence created by the interaction of internal waves with the margin topography, which intensifies near-bottom water movements. These internal waves are able to move on the density gradient between water masses, which are located at 225 and $300 \mathrm{~m}$ depth (Fig. 3). Tidal waves will be amplified due to a critical match between the characteristic slope of the internal M2 tide and the bottom slope of the Angolan margin, as is known from other continental slope regions (Dickson and McCave, 1986; Mienis et al., 2007). As argued above, this turbid layer is likely important for the nutrition of the slightly deeper situated CWC mounds, since vertical mixing is otherwise hindered by the strong stratification.

\section{Conclusions}

Different environmental properties explain the present conditions of the benthic communities on the southwestern African margin including temperature, DO concentration, food supply and tidal movements. The DO concentrations probably define the limits of a suitable habitat for CWCs along the Namibian and the Angolan margin, whereas high temperatures constitute additional stress by increasing the respiration rate and therefore energy demand. On the Namibian margin, where DO concentrations dropped below $0.01 \mathrm{mLL}^{-1}$, only fossil CWC mounds covered by a community dominated by sponges and bryozoans were found. This benthic community survives as it receives periodically waters with slightly higher 
DO concentrations $\left(>0.03 \mathrm{mLL}^{-1}\right)$ due to regular tidal oscillations (semidiurnal) and erratic wind events (seasonal). At the same time, a high quality and quantity of SPOM sinking down from the surface water mass enables the epifaunal community to survive despite the oxygen stress and to sustain its metabolic energy demand at the Namibian OMZ, while CWCs are not capable to withstand such extreme conditions. In contrast, thriving CWCs on the Angolan coral mounds were encountered despite the overall hypoxic conditions. The DO concentrations were slightly higher than those on the Namibian margin but nevertheless below the lowest threshold that was so far reported for L. pertusa (Ramos et al., 2017; Davies et al., 2008, 2010). In combination with temperatures close to the upper limits for $L$. pertusa, metabolic energy demand probably reached a maximum. High energy requirements might have been compensated by the general high availability of fresh resuspended SPOM. Fresh SPOM accumulates on the Angolan margin just above the CWC area and is regularly supplied due to mixing by semidiurnal tidal currents, despite the restricted sinking of SPOM from the surface due to the strong stratification.

CWC and sponge communities are known to play an important role as a refuge, feeding ground and nursery for commercial fishes (Miller et al., 2012), and have a crucial role in the marine benthic pelagic coupling (Cathalot et al., 2015). Their ecosystem services are threatened by the expected expansion of OMZs due to anthropogenic activities like rising nutrient loads and climate change (Breitburg et al., 2018). This study showed that benthic fauna is able to cope with low oxygen levels as long as sufficient high-quality food is available. Further, reef-associated sponge grounds, as encountered on the Namibian margin could play a crucial role in taking over the function of CWCs in marine carbon cycling as well as in providing a habitat for associated fauna, when conditions become unsuitable for CWCs.

Data availability. CTD data presented in this work are available at https://doi.pangaea.de/10.1594/PANGAEA.904176 (Hebbeln, 2019). Lander time series data were submitted to Pangaea and are also available at the NIOZ data archive system (https://doi.org/10.25850/nioz/7b.b.q, Hanz, 2019).

Author contributions. UH analyzed the physical and chemical data, wrote the paper and prepared the figures with contributions from all authors. FM, GD and ML designed the lander research. DH and CW led the cruise and wrote the initial cruise plan. FM and ML collected the data during the research cruise. WCD was responsible for water column measurements with the CTD. AF and ML provided habitat characteristics, including species identification of both CWC areas. $\mathrm{KJ}$ performed the tidal analysis and provided together with SF data from the SML lander. All authors contributed to the data interpretation and discussion of the paper.
Competing interests. The authors declare that they have no conflict of interest.

Acknowledgements. We thank the captain of the RV Meteor cruise M122, Rainer Hammacher, his officers and crew, who contributed to the success of this cruise. We also would like to thank the scientific and technical staff for their assistance during the cruise and their work in the laboratory. Greatly acknowledged are the efforts from the German Diplomatic Corps in the German embassies in Windhoek and Luanda and in the Foreign Office in Berlin. We thank the German Science Foundation (DFG) for providing ship time on RV Meteor and for funding the ROV Squid operations to investigate the cold-water coral ecosystems off Angola and Namibia.

Financial support. This research has been supported by the DFG Research Center/Cluster of Excellence "MARUM - The Ocean in the Earth System". Ulrike Hanz is funded by the SponGES project, which received funding from the European Union's Horizon 2020 research and innovation program (grant no. 679849). Furu Mienis is supported by the Innovational Research Incentives Scheme of the Netherlands Organisation for Scientific Research (NWO-VIDI grant no. 016.161.360). Gert-Jan Reichart is supported by the Netherlands Earth System Science Centre (NESSC), financially supported by the Ministry of Education, Culture and Science (OCW). Katriina Juva is funded through the FATE project (Fate of cold-water coral reefs - identifying drivers of ecosystem change), supported by the Norwegian Research Council (NRC).

Review statement. This paper was edited by Stefano Ciavatta and reviewed by two anonymous referees.

\section{References}

Boutton, T. W.: Stable carbon isotope ratios of natural materials: II. Atmospheric, terrestrial, marine, and freshwater environments, Carbon Isotope Techniques, 1, 173-186, 1991.

Breitburg, D., Levin, L. A., Oschlies, A., Grégoire, M., Chavez, F. P., Conley, D. J., Garçon, V., Gilbert, D., Gutiérrez, D., and Isensee, K.: Declining oxygen in the global ocean and coastal waters, Science, 359, 1-11, 2018.

Brooke, S. and Ross, S. W.: First observations of the cold-water coral Lophelia pertusa in mid-Atlantic canyons of the USA, Deep-Sea Res. Pt. II, 104, 245-251, 2014.

Buhl-Mortensen, L., Vanreusel, A., Gooday, A. J., Levin, L. A., Priede, I. G., Buhl-Mortensen, P., Gheerardyn, H., King, N. J., and Raes, M.: Biological structures as a source of habitat heterogeneity and biodiversity on the deep ocean margins, Mar. Ecol., 31, 21-50, 2010.

Cairns, S. D.: Deep-water corals: an overview with special reference to diversity and distribution of deep-water scleractinian corals, B. Mar. Sci., 81, 311-322, 2007.

Carr, M.-E. and Kearns, E. J.: Production regimes in four Eastern Boundary Current systems, Deep-Sea Res. Pt. II, 50, 3199-3221, 2003. 
Cathalot, C., Van Oevelen, D., Cox, T. J., Kutti, T., Lavaleye, M., Duineveld, G., and Meysman, F. J.: Cold-water coral reefs and adjacent sponge grounds: Hotspots of benthic respiration and organic carbon cycling in the deep sea, Front. Mar. Sci., 2, 2-37, 2015.

Chapman, P. and Shannon, L.: The Benguela ecosystem, Part II, Chemistry and related processes, Oceanogr. Mar. Biol., 23, 183251, 1985 .

Chapman, P. and Shannon, L.: Seasonality in the oxygen minimum layers at the extremities of the Benguela system, S. Afr. J. Marine Sci., 5, 85-94, 1987.

Coma, R.: Seasonality of in situ respiration rate in three temperate benthic suspension feeders, Limnol. Oceanogr., 47, 324-331, 2002.

Costello, M. J., McCrea, M., Freiwald, A., Lundälv, T., Jonsson, L., Bett, B. J., van Weering, T. C., de Haas, H., Roberts, J. M., and Allen, D.: Role of cold-water Lophelia pertusa coral reefs as fish habitat in the NE Atlantic, in: Cold-water corals and ecosystems, Springer, Heidelberg, 771-805, 2005.

Davies, A. J. and Guinotte, J. M.: Global habitat suitability for framework-forming cold-water corals, PloS one, 6, e18483, https://doi.org/10.1371/journal.pone.0018483, 2011.

Davies, A. J., Wisshak, M., Orr, J. C., and Roberts, J. M.: Predicting suitable habitat for the cold-water coral Lophelia pertusa (Scleractinia), Deep-Sea Res. Pt. I, 55, 1048-1062, 2008.

Davies, A. J., Duineveld, G. C., Lavaleye, M. S., Bergman, M. J., van Haren, H., and Roberts, J. M.: Downwelling and deep-water bottom currents as food supply mechanisms to the cold-water coral Lophelia pertusa (Scleractinia) at the Mingulay Reef Complex, Limnol. Oceanogr., 54, 620-629, 2009.

Davies, A. J., Duineveld, G. C., van Weering, T. C., Mienis, F., Quattrini, A. M., Seim, H. E., Bane, J. M., and Ross, S. W.: Short-term environmental variability in cold-water coral habitat at Viosca Knoll, Gulf of Mexico, Deep-Sea Res. Pt. I, 57, 199212,2010

De Haas, H., Mienis, F., Frank, N., Richter, T. O., Steinacher, R., De Stigter, H., Van der Land, C., and Van Weering, T. C.: Morphology and sedimentology of (clustered) cold-water coral mounds at the south Rockall Trough margins, NE Atlantic Ocean, Facies, 55, 1-26, 2009.

Diaz, R. J. and Rosenberg, R.: Marine benthic hypoxia: a review of its ecological effects and the behavioural responses of benthic macrofauna, Oceanography and Marine Biology, Ann. Rev., 33, 245-203, 1995.

Dickson, R. and McCave, I.: Nepheloid layers on the continental slope west of Porcupine Bank, Deep-Sea Res. Pt. A, 33, 791818,1986

Dodds, L., Roberts, J., Taylor, A., and Marubini, F.: Metabolic tolerance of the cold-water coral Lophelia pertusa (Scleractinia) to temperature and dissolved oxygen change, J. Exp. Mar. Biol. Ecol., 349, 205-214, 2007.

Dodds, L., Black, K., Orr, H., and Roberts, J.: Lipid biomarkers reveal geographical differences in food supply to the cold-water coral Lophelia pertusa (Scleractinia), Mar. Ecol. Prog. Ser., 397, 113-124, 2009.

Duineveld, G. C., Lavaleye, M. S., Bergman, M. J., De Stigter, H., and Mienis, F.: Trophic structure of a cold-water coral mound community (Rockall Bank, NE Atlantic) in relation to the near- bottom particle supply and current regime, B. Mar. Sci., 81, 449467, 2007.

Dullo, W.-C., Flögel, S., and Rüggeberg, A.: Cold-water coral growth in relation to the hydrography of the Celtic and Nordic European continental margin, Mar. Ecol. Prog. Ser., 371, 165176, 2008.

Eisele, M., Frank, N., Wienberg, C., Hebbeln, D., Correa, M. L., Douville, E., and Freiwald, A.: Productivity controlled coldwater coral growth periods during the last glacial off Mauritania, Mar. Geol., 280, 143-149, 2011.

Fink, H. G., Wienberg, C., Hebbeln, D., McGregor, H. V., Schmiedl, G., Taviani, M., and Freiwald, A.: Oxygen control on Holocene cold-water coral development in the eastern Mediterranean Sea, Deep-Sea Res. Pt. I, 62, 89-96, 2012.

Flögel, S., Dullo, W.-C., Pfannkuche, O., Kiriakoulakis, K., and Rüggeberg, A.: Geochemical and physical constraints for the occurrence of living cold-water corals, Deep-Sea Res. Pt. II, 99, 19-26, 2014.

Frederiksen, R., Jensen, A., and Westerberg, H.: The distribution of the scleractinian coral Lophelia pertusa around the Faroe Islands and the relation to internal tidal mixing, Sarsia, 77, 157171, 1992.

Freiwald, A.: Reef-forming cold-water corals, in: Ocean margin systems, Springer, 365-385, 2002.

Freiwald, A., Fossa, J. H., Grehan, A., Koslow, T., and Roberts, J. M.: Cold water coral reefs: out of sight-no longer out of mind, No.22 in Biodiversity Series, UNEP-WCMC, Cambridge, UK, 1-86, 2004.

Freiwald, A., Beuck, L., Rüggeberg, A., Taviani, M., Hebbeln, D., and Participants, R. V. M. C. M.: The white coral community in the central Mediterranean Sea revealed by ROV surveys, Oceanography, 22, 58-74, 2009.

Geissler, W., Schwenk, T., and Wintersteller, P.: Walvis Ridge Passive-Source Seismic Experiment (WALPASS), Cruise No. MSM20/1, 6-15 January 2012, Cape Town (South Africa), Walvis Bay (Namibia), DFG-Senatskommission für Ozeanographie, MARIA S. MERIAN-Berichte, MSM20/1, 54 pp., 2013.

Gibson, R. N. and Atkinson, R. J. A.: Oxygen minimum zone benthos: adaptation and community response to hypoxia, Oceanogr. Mar. Biol. Annu. Rev., 41, 1-45, 2003.

Gori, A., Grover, R., Orejas, C., Sikorski, S., and Ferrier-Pagès, C.: Uptake of dissolved free amino acids by four cold-water coral species from the Mediterranean Sea, Deep-Sea Res. Pt. II, 99, 42-50, 2014

Grasmueck, M., Eberli, G. P., Viggiano, D. A., Correa, T., Rathwell, G., and Luo, J.: Autonomous underwater vehicle (AUV) mapping reveals coral mound distribution, morphology, and oceanography in deep water of the Straits of Florida, Geophys. Res. Lett., 33, L23616, https://doi.org/10.1029/2006GL027734, 2006.

Hanz, U.: Lander data ALBEX, available at: https://doi.org/10.25850/nioz/7b.b.q, last access: 24 October 2019 .

Hebbeln, D.: CTD-data from RV Meteor cruise M122 in 2016 off Angola, PANGAEA, available at: https://doi.org/10.1594/PANGAEA.904176, last access: 24 October 2019.

Hebbeln, D., Wienberg, C., Wintersteller, P., Freiwald, A., Becker, M., Beuck, L., Dullo, C., Eberli, G. P., Glogowski, S., Matos, L., Forster, N., Reyes-Bonilla, H., and Taviani, M.: Environ- 
mental forcing of the Campeche cold-water coral province, southern Gulf of Mexico, Biogeosciences, 11, 1799-1815, https://doi.org/10.5194/bg-11-1799-2014, 2014.

Hebbeln, D., Wienberg, C., Bender, M., Bergmann, F., Dehning, K., Dullo, W.-C., Eichstädter, R., Flöter, S., Freiwald, A., Gori, A., Haberkern, J., Hoffmann, L., João, F., Lavaleye, M., Leymann, T., Matsuyama, K., Meyer-Schack, B., Mienis, F., Moçambique, I., Nowald, N., Orejas, C., Ramos Cordova, C., Saturov, D., Seiter, C., Titschack, J., Vittori, V., Wefing, A.-M., Wilsenack, M., and Wintersteller, P.: ANNA Cold-Water Coral Ecosystems off Angola and Namibia, Cruise No. M122, 30 December 2015-31 January 2016, Walvis Bay (Namibia), Walvis Bay (Namibia), METEOR-Berichte, M122, https://doi.org/10.2312/cr_m122, 2017.

Hebbeln, D., Wienberg, C., Dullo, W. C., Freiwald, A., Mienis, F., Orejas, C., and Titschack, J.: Cold-water corals thriving in hypoxia, Nat. Commun., submitted, https://doi.org/10.1594/PANGAEA.904176, 2019.

Hedges, J. and Oades, J.: Comparative organic geochemistries of soils and marine sediments, Org. Geochem., 27, 319-361, 1997.

Henry, L.-A. and Roberts, J. M.: Biodiversity and ecological composition of macrobenthos on cold-water coral mounds and adjacent off-mound habitat in the bathyal Porcupine Seabight, NE Atlantic, Deep-Sea Res. Pt. I, 54, 654-672, 2007.

Henry, L.-A. and Roberts, J. M.: Global Biodiversity in Cold-Water Coral Reef Ecosystems, in: Marine Animal Forests, Springer, 235-256, 2017.

Holmes, M. E., Schneider, R. R., Müller, P. J., Segl, M., and Wefer, G.: Reconstruction of past nutrient utilization in the eastern Angola Basin based on sedimentary ${ }^{15} \mathrm{~N} /{ }^{14} \mathrm{~N}$ ratios, Paleoceanography, 12, 604-614, 1997.

Hutchings, L., Van der Lingen, C., Shannon, L., Crawford, R., Verheye, H., Bartholomae, C., Van der Plas, A., Louw, D., Kreiner, A., and Ostrowski, M.: The Benguela Current: An ecosystem of four components, Prog. Oceanogr., 83, 15-32, 2009.

Junker, T., Mohrholz, V., Siegfried, L., and van der Plas, A.: Seasonal to interannual variability of water mass characteristics and currents on the Namibian shelf, J. Mar. Syst., 165, 36-46, 2017.

Karstensen, J., Stramma, L., and Visbeck, M.: Oxygen minimum zones in the eastern tropical Atlantic and Pacific oceans, Prog. Oceanogr., 77, 331-350, 2008.

Kiriakoulakis, K., Fisher, E., Wolff, G. A., Freiwald, A., Grehan, A., and Roberts, J. M.: Lipids and nitrogen isotopes of two deepwater corals from the North-East Atlantic: initial results and implications for their nutrition, in: Cold-water corals and ecosystems, edited by: Freiwald, A. A. and Roberts, J. M., Springer, Heidelberg, 715-729, 2005.

Kiriakoulakis, K., Freiwald, A., Fisher, E., and Wolff, G.: Organic matter quality and supply to deep-water coral/mound systems of the NW European Continental Margin, Int. J. Earth Sci., 96, 159170, 2007.

Kopte, R., Brandt, P., Dengler, M., Tchipalanga, P., Macuéria, M., and Ostrowski, M.: The Angola Current: Flow and hydrographic characteristics as observed at $11^{\circ} \mathrm{S}, \mathrm{J}$. Geophys. Res.-Ocean., 122, 1177-1189, 2017.

Kostianoy, A. and Lutjeharms, J.: Atmospheric effects in the Angola-Benguela frontal zone, J. Geophys. Res.-Ocean., 104, 20963-20970, 1999.
Kraay, G. W., Zapata, M., and Veldhuis, M. J.: Separation of Chlorophylls c1c2, and c3 of marine Phytoplankton by Reverse Phase C18 high Performance liquid Chromatography 1, J. Phycol., 28, 708-712, 1992.

Le Guilloux, E., Olu, K., Bourillet, J.-F., Savoye, B., Iglésias, S., and Sibuet, M.: First observations of deep-sea coral reefs along the Angola margin, Deep-Sea Res. Pt. II, 56, 2394-2403, 2009.

Levin, L. A., Huggett, C. L., and Wishner, K. F.: Control of deepsea benthic community structure by oxygen and organic-matter gradients in the eastern Pacific Ocean, J. Mar. Res., 49, 763-800, 1991.

Lutjeharms, J. and Stockton, P.: Kinematics of the upwelling front off southern Africa, South Afr. J. Mar. Sci., 5, 35-49, 1987.

Mariotti, A., Gadel, F., and Giresse, P.: Carbon isotope composition and geochemistry of particulate organic matter in the Congo River (Central Africa): application to the study of Quaternary sediments off the mouth of the river, Chem. Geol., 86, 345-357, 1991.

Meisel, S., Struck, U., and Emeis, K.-C.: Nutrient dynamics and oceanographic features in the central Namibian upwelling region as reflected in $\delta^{15} \mathrm{~N}$-signals of suspended matter and surface sediments, Foss. Rec., 14, 153-169, https://doi.org/10.1002/mmng.201100005, 2011.

Mienis, F., De Stigter, H., White, M., Duineveld, G., De Haas, H., and Van Weering, T.: Hydrodynamic controls on cold-water coral growth and carbonate-mound development at the SW and SE Rockall Trough Margin, NE Atlantic Ocean, Deep-Sea Res. Pt. I, 54, 1655-1674, 2007.

Mienis, F., De Stigter, H., De Haas, H., and Van Weering, T.: Nearbed particle deposition and resuspension in a cold-water coral mound area at the Southwest Rockall Trough margin, NE Atlantic, Deep-Sea Res. Pt. I, 56, 1026-1038, 2009.

Mienis, F., Duineveld, G., Davies, A., Ross, S., Seim, H., Bane, J., and Van Weering, T.: The influence of near-bed hydrodynamic conditions on cold-water corals in the Viosca Knoll area, Gulf of Mexico, Deep-Sea Res. Pt. I, 60, 32-45, 2012.

Mienis, F., Duineveld, G. C. A., Davies, A. J., Lavaleye, M. M. S., Ross, S. W., Seim, H., Bane, J., van Haren, H., Bergman, M. J. N., de Haas, H., Brooke, S., and van Weering, T. C. E.: Coldwater coral growth under extreme environmental conditions, the Cape Lookout area, NW Atlantic, Biogeosciences, 11, 2543 2560, https://doi.org/10.5194/bg-11-2543-2014, 2014.

Miller, R. J., Hocevar, J., Stone, R. P., and Fedorov, D. V.: Structure-forming corals and sponges and their use as fish habitat in Bering Sea submarine canyons, PLoS One, 7, e33885, https://doi.org/10.1371/journal.pone.0033885, 2012.

Mills, D. B., Francis, W. R., Vargas, S., Larsen, M., Elemans, C. P., Canfield, D. E., and Wörheide, G.: The last common ancestor of animals lacked the HIF pathway and respired in low-oxygen environments, eLife, 7, e31176, https://doi.org/10.7554/eLife.31176, 2018.

Mohrholz, V., Bartholomae, C., Van der Plas, A., and Lass, H.: The seasonal variability of the northern Benguela undercurrent and its relation to the oxygen budget on the shelf, Cont. Shelf Res., 28, 424-441, 2008.

Mohrholz, V., Eggert, A., Junker, T., Nausch, G., Ohde, T., and Schmidt, M.: Cross shelf hydrographic and hydrochemical conditions and their short term variability at the northern Benguela 
during a normal upwelling season, J. Mar. Syst., 140, 92-110, 2014.

Montoya, J. P.: Natural abundance of ${ }^{15} \mathrm{~N}$ in marine planktonic ecosystems, in: Stable isotopes in ecology and environmental science, edited by: Michener, R. and Lajtha, K., 2nd Edn., Blackwell, Malden, MA, 176-202, 2007.

Mortensen, P. B., Hovland, T., Fosså, J. H., and Furevik, D. M.: Distribution, abundance and size of Lophelia pertusa coral reefs in mid-Norway in relation to seabed characteristics, J. Mar. Biol. Assoc. UK, 81, 581-597, 2001.

Mosch, T., Sommer, S., Dengler, M., Noffke, A., Bohlen, L., Pfannkuche, O., Liebetrau, V., and Wallmann, K.: Factors influencing the distribution of epibenthic megafauna across the Peruvian oxygen minimum zone, Deep-Sea Res. Pt. I, 68, 123-135, 2012

Mueller, C. E., Larsson, A. I., Veuger, B., Middelburg, J. J., and van Oevelen, D.: Opportunistic feeding on various organic food sources by the cold-water coral Lophelia pertusa, Biogeosciences, 11, 123-133, https://doi.org/10.5194/bg-11-123-2014, 2014

Mullins, H. T., Thompson, J. B., McDougall, K., and Vercoutere, T. L.: Oxygen-minimum zone edge effects: evidence from the central California coastal upwelling system, Geology, 13, 491494, 1985

Odum, H. T.: Environment, power and society, New York, USA, Wiley-Interscience, 1-131, 1971.

Oevelen, D. v., Duineveld, G., Lavaleye, M., Mienis, F., Soetaert, K., and Heip, C. H.: The cold-water coral community as hotspot of carbon cycling on continental margins: A food-web analysis from Rockall Bank (northeast Atlantic), Limnol. Oceanogr., 54, 1829-1844, 2009.

Pawlowicz, R., Beardsley, B., and Lentz, S.: Classical tidal harmonic analysis including error estimates in MATLAB using T_TIDE, Comput. Geosci., 28, 929-937, 2002.

Perdue, E. M. and Koprivnjak, J.-F.: Using the $\mathrm{C} / \mathrm{N}$ ratio to estimate terrigenous inputs of organic matter to aquatic environments, Estuarine, Coast. Shelf Sci., 73, 65-72, 2007.

Poole, R. and Tomczak, M.: Optimum multiparameter analysis of the water mass structure in the Atlantic Ocean thermocline, Deep-Sea Res. Pt. I, 46, 1895-1921, 1999.

Rae, C. D.: A demonstration of the hydrographic partition of the Benguela upwelling ecosystem at $26^{\circ} 40^{\prime}$ S, Afr. J. Mar. Sci., 27, 617-628, 2005.

R Core Team, R. C.: R: A language and environment for statistical computing, Vienna, Austria, 2017.

Ramos, A., Sanz, J. L., Ramil, F., Agudo, L. M., and PresasNavarro, C.: The Giant Cold-Water Coral Mounds Barrier Off Mauritania, in: Deep-Sea Ecosystems Off Mauritania, edited by: Ramos, A., Ramil, F., and Sanz, J. L., Springer, 481-525, 2017.

Roberts, J. M., Wheeler, A. J., and Freiwald, A.: Reefs of the deep: the biology and geology of cold-water coral ecosystems, Science, 312, 543-547, 2006.

Ruhl, H. A.: Community change in the variable resource habitat of the abyssal northeast Pacific, Ecology, 89, 991-1000, 2008.

Sanders, H.: Benthic marine diversity and the stability-time hypothesis, Brookhaven Sym. Biol., 1969, 71-81, 1969.

Schlitzer, R.: Ocean Data View, available at: http://odv.awi.de (last access: 12 February 2016), 2011.
Schroeder, W.: Observations of Lophelia pertusa and the surficial geology at a deep-water site in the northeastern Gulf of Mexico, Hydrobiologia, 471, 29-33, 2002.

Shannon, L.: Benguela Current, Ocean Currents: A Derivative of Encyclopedia of Ocean Sciences, 23-34, 2001.

Shannon, L. and Nelson, G.: The Benguela: large scale features and processes and system variability, in: The South Atlantic, Springer, Berlin, Heidelberg, 163-210, 1996.

Shannon, L., Boyd, A., Brundrit, G., and Taunton-Clark, J.: On the existence of an El Niño-type phenomenon in the Benguela system, J. Mar. Res., 44, 495-520, 1986.

Shannon, L., Agenbag, J., and Buys, M.: Large-and mesoscale features of the Angola-Benguela front, South Afr. J. Mar. Sci., 5, 11-34, 1987.

Sigman, D. M., DiFiore, P. J., Hain, M. P., Deutsch, C., and Karl, D. M.: Sinking organic matter spreads the nitrogen isotope signal of pelagic denitrification in the North Pacific, Geophys. Res. Lett., 36, L08605, https://doi.org/10.1029/2008GL035784, 2009.

Sokolova, I. M., Frederich, M., Bagwe, R., Lannig, G., and Sukhotin, A. A.: Energy homeostasis as an integrative tool for assessing limits of environmental stress tolerance in aquatic invertebrates, Mar. Environ. Res., 79, 1-15, 2012.

Tahey, T., Duineveld, G., Berghuis, E., and Helder, W.: Relation between sediment-water fluxes of oxygen and silicate and faunal abundance at continental shelf, slope and deep-water stations in the northwest Mediterranean, Mar. Ecol. Prog. Ser., 104, 119$130,1994$.

Tamborrino, L., Wienberg, C., Titschack, J., Wintersteller, P., Mienis, F., Freiwald, A., Orejas, C., Dullo, W.-C., Haberkern, J., and Hebbeln, D.: Mid-Holocene extinction of cold-water corals on the Namibian shelf steered by the Benguela oxygen minimum zone, Geology, 47, 14, https://doi.org/10.1130/646672.1, 2019., 2019.

Taviani, M., Remia, A., Corselli, C., Freiwald, A., Malinverno, E., Mastrototaro, F., Savini, A., and Tursi, A.: First geo-marine survey of living cold-water Lophelia reefs in the Ionian Sea (Mediterranean basin), Facies, 50, 409-417, 2005.

Thiem, Ø., Ravagnan, E., Fosså, J. H., and Berntsen, J.: Food supply mechanisms for cold-water corals along a continental shelf edge, J. Marine Syst., 60, 207-219, 2006.

Titschack, J., Baum, D., De Pol-Holz, R., Lopez Correa, M., Forster, N., Flögel, S., Hebbeln, D., and Freiwald, A.: Aggradation and carbonate accumulation of Holocene Norwegian cold-water coral reefs, Sedimentology, 62, 1873-1898, 2015.

Tyrrell, T. and Lucas, M. I.: Geochemical evidence of denitrification in the Benguela upwelling system, Cont. Shelf Res., 22, 2497 2511, 2002.

van Haren, H., Mienis, F., Duineveld, G. C., and Lavaleye, M. S.: High-resolution temperature observations of a trapped nonlinear diurnal tide influencing cold-water corals on the Logachev mounds, Prog. Oceanogr., 125, 16-25, 2014.

van Soest, R. W., Cleary, D. F., de Kluijver, M. J., Lavaleye, M. S., Maier, C., and van Duyl, F. C.: Sponge diversity and community composition in Irish bathyal coral reefs, Contrib. Zool., 76, 121142, 2007.

Wefing, A. M., Arps, J., Blaser, P., Wienberg, C., Hebbeln, D., and Frank, N.: High precision U-series dating of scleractinian coldwater corals using an automated chromatographic U and Th extraction, Chem. Geol., 475, 140-148, 2017. 
Welschmeyer, N. A. and Lorenzen, C. J.: Chlorophyll budgets: Zooplankton grazing and phytoplankton growth in a temperate fjord and the Central Pacific Gyres1, Limnol. Oceanogr., 30, 1-21, 1985.

Wheeler, A. J., Beyer, A., Freiwald, A., De Haas, H., Huvenne, V., Kozachenko, M., Olu-Le Roy, K., and Opderbecke, J.: Morphology and environment of cold-water coral carbonate mounds on the NW European margin, Int. J. Earth Sci., 96, 37-56, 2007.

White, M., Mohn, C., de Stigter, H., and Mottram, G.: Deep-water coral development as a function of hydrodynamics and surface productivity around the submarine banks of the Rockall Trough, NE Atlantic, in: Cold-water corals and ecosystems, edited by: Freiwald, A. and Roberts, J. M., Springer, Heidelberg, 503-514, 2005.

White, M., Wolff, G. A., Lundälv, T., Guihen, D., Kiriakoulakis, K., Lavaleye, M., and Duineveld, G.: A Freiwald, JM Roberts, Coldwater coral ecosystem (Tisler Reef, Norwegian Shelf) may be a hotspot for carbon cycling, Mar. Ecol. Prog. Ser., 465, 11-23, 2012.
Wienberg, C. and Titschack, J.: Framework-forming scleractinian cold-water corals through space and time: a late Quaternary North Atlantic perspective, in: Marine Animal Forests: the Ecology of Benthic Biodiversity Hotspots, edited by: Rossi, S., Bramanti, L., Gori, A., and Orejas, C., Springer, 699-732, 2017.

Wienberg, C., Titschack, J., Freiwald, A., Frank, N., Lundälv, T., Taviani, M., Beuck, L., Schröder-Ritzrau, A., Krengel, T., and Hebbeln, D.: The giant Mauritanian cold-water coral mound province: Oxygen control on coral mound formation, Quaternary Sci. Rev., 185, 135-152, 2018.

Wilson, J.: "Patch" development of the deep-water coral Lophelia pertusa (L.) on Rockall Bank, J. Mar. Biol. Assoc. UK, 59, 165 177, 1979.

Zabel, M., Boetius, A., Emeis, K.-C., Ferdelman, T. G., and Spieß, V.: PROSA Process Studies in the Eastern South Atlantic, Cruise No. M76, 12-24 August 2008, Cape Town (South Africa), Walvis Bay (Namibia), DFG Senatskommission für Ozeanographie, METEOR-Berichte, M76, 180 pp., 2012. 